\title{
WEB BASED COST MANAGEMENT TOOL PROTOTYPE DEVELOPMENT USING TEMPORAL-ACTIVITY BASED COSTING (Temporal-ABC ${ }^{\circledR}$ )
}

\author{
By \\ Mourougavelou Vaithianathan, \\ B.Tech. (Mechanical Engineering), \\ Pondicherry University (India), 1997
}

\begin{abstract}
A project
presented to Ryerson University

in partial fulfillment of the requirement for the degree of

Masters of Engineering

in the Program of Mechanical Engineering
\end{abstract}

Toronto, Ontario, Canada, 2006

(C) Mourougavelou Vaithianathan 2006 
UMI Number: EC53544

\section{INFORMATION TO USERS}

The quality of this reproduction is dependent upon the quality of the copy submitted. Broken or indistinct print, colored or poor quality illustrations and photographs, print bleed-through, substandard margins, and improper alignment can adversely affect reproduction.

In the unlikely event that the author did not send a complete manuscript and there are missing pages, these will be noted. Also, if unauthorized copyright material had to be removed, a note will indicate the deletion.

\section{$\mathrm{UMI}^{\circ}$}

UMI Microform EC53544

Copyright 2009 by ProQuest LLC

All rights reserved. This microform edition is protected against unauthorized copying under Title 17, United States Code.

ProQuest LLC

789 East Eisenhower Parkway

P.O. Box 1346

Ann Arbor, MI 48106-1346 
I hereby declare that I am the sole author of this research report.

I authorize Ryerson University to lend this research report to other institutions or individuals for the purpose of scholarly research.

Mourougavelou Vaithianathan

I further authorize Ryerson University to reproduce this research report by photocopying or by other means, in total or in part, at the request of other institutions or individuals for the purpose of scholarly research.

Mourougavelou Vaithianathan 
Ryerson University requires the signatures of all persons using or photocopying this research report. Please sign below, and give the address and the date.

\begin{tabular}{|c|c|c|c|}
\hline Name & Signature & Address & Date \\
\hline & & & \\
\hline & & & \\
\hline & & & \\
\hline & & & \\
\hline & & & \\
\hline & & & \\
\hline & & & \\
\hline & & & \\
\hline & & & \\
\hline & & & \\
\hline & & & \\
\hline & & & \\
\hline & & & \\
\hline & & & \\
\hline & & & \\
\hline & & & \\
\hline & & & \\
\hline & & & \\
\hline & & & \\
\hline & & & \\
\hline & & & \\
\hline & & & \\
\hline & & & \\
\hline & & & \\
\hline & & & \\
\hline & & & \\
\hline & & & \\
\hline & & & \\
\hline & & & \\
\hline & & & \\
\hline & & & \\
\hline
\end{tabular}




\title{
Web Based Cost Management Tool Prototype Development Using Temporal-Activity Based Costing (Temporal-ABC ${ }^{\circledR}$ )
}

\author{
(C) Mourougavelou Vaithianathan \\ Masters of Engineering \\ in the Program of Mechanical Engineering \\ Ryerson University
}

\begin{abstract}
The cost management system is a powerful tool for managers to understand manufacturing plant performance. It is essential for any organization to develop a cost management system to estimate the product cost and to account actual cost spent for the product manufacturing. The Activity Based Costing ( $\mathrm{ABC}$ ) system has recently attracted the attention of many companies and is considered to provide better information about the cost pattern and the relationship between resources and activities. However, a survey of earlier research reveals that there are several difficulties to estimate the true product cost due to selection of overhead drivers to activities. To overcome these difficulties Temporal-ABC ${ }^{\circledR *}$ has been developed by Dr.K.D.Tham.
\end{abstract}

In the first part of the report, costing system implementation issues are studied through real-time case studies. Then, research has been conducted and web-based prototype application is developed using Temporal-ABC ${ }^{\circledR}$ through collaboration with a world-class electronics industry - Celestica Inc. Toronto, Canada. The developed prototype demonstrates the application of $\mathrm{Temporal}_{-} \mathrm{ABC}^{\circledR}$ for cost estimation at Celestica.

* Temporal-ABC ${ }^{\circledR}$ is trademark of Nulogoy Corporation, Co-founded by Dr.K.DonaldTham 


\section{Acknowledgements}

First of all, I would like to thank my supervisor Dr. K. Donald Tham, for everything I have learned from working with him during the year and a half of my graduate studies, for his advice, his enormous patience and for being more of a friend than a boss.

I would like to thank Ms. Andrea Strachan, Mr. Manny Panesar and Mr. Jason Snaggs, at Celestica Inc., Toronto, for their help and guidance towards the successful completion of the project.

I would like to thank Ms. Kevin McGarrigle-Schlosser, from Action Profile System for providing me with flexible working hours. 


\section{Table of Contents}

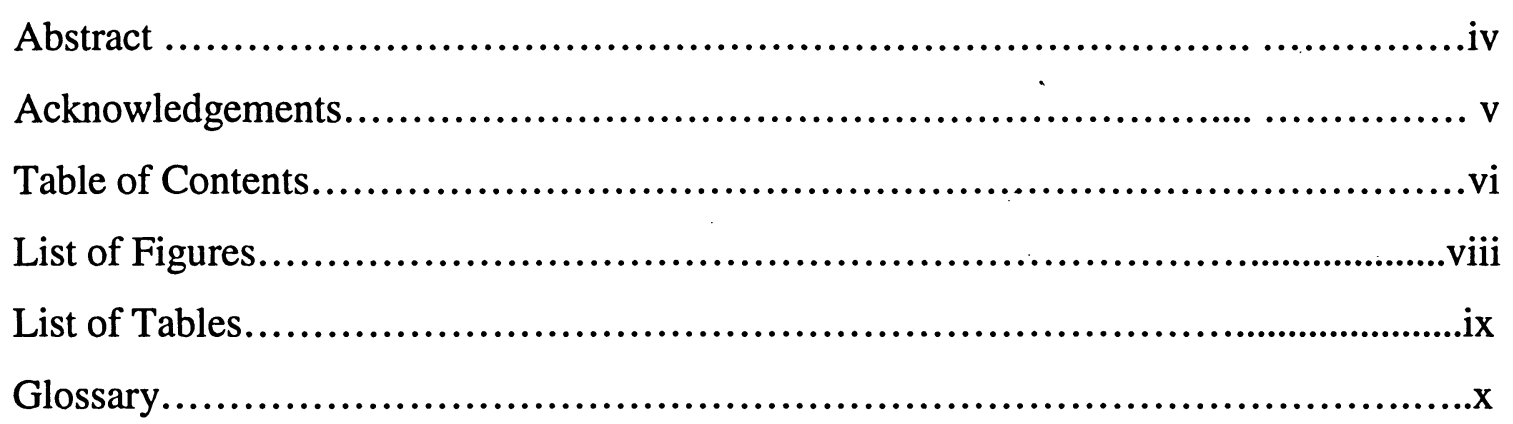

\section{Chapter 1. Introduction}

1.1 Motivation...................................................................1

1. 2 Research Goals and the Author's Contribution....................................2

1.3 Research Project Organization...................................................2

\section{Chapter 2. Background}

2.1 Traditional Costing Systems: An Overview......................................4

2.2 Activity Based Costing.........................................................5

2.2.1 Temporal-ABC: An Overview...........................................8

$2.3 \mathrm{ABC}$ Implementation Issues.................................................

2.3.1 ABC Implementation Failure .........................................9

2.3.2 ABC Implementation Success Strategies...............................16

\section{Chapter 3. Company Analysis-Celestica Inc. Toronto}

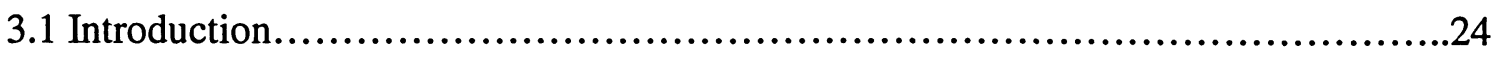

3.2 Product Details...............................................................24

3.3 Process Details............................................................25 
3.4 The Existing Costing Methodology ............................................28

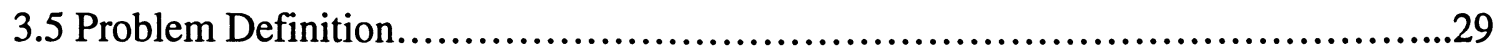

3.6 Proposed Solution...............................................................30

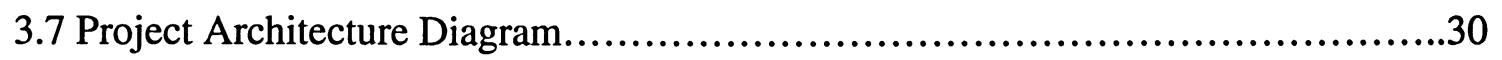

\section{Chapter 4. Prototype Development}

4.1 Description of Cost Management Tool.........................................32

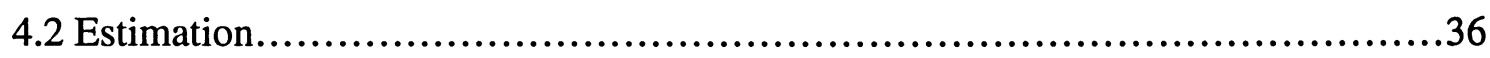

4.3 Actual Manufacturing Cost.......................................................43

4.3.1 Different Types of Cost Accounting Systems.............................44

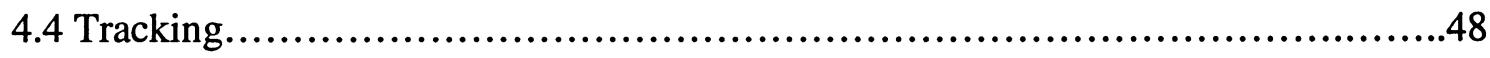

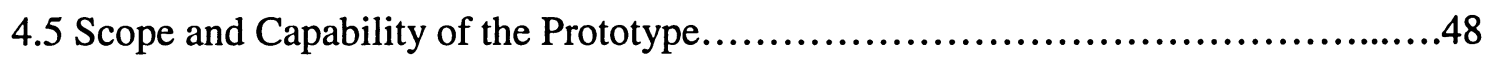

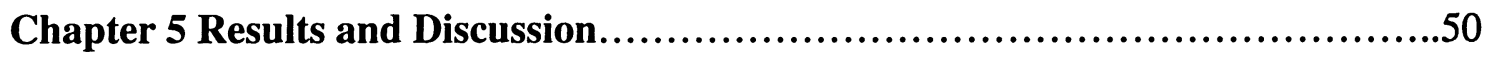

\section{Chapter 6 Conclusion and Future Work}

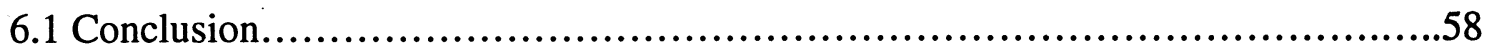

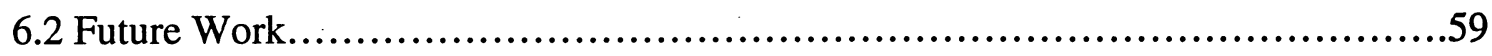

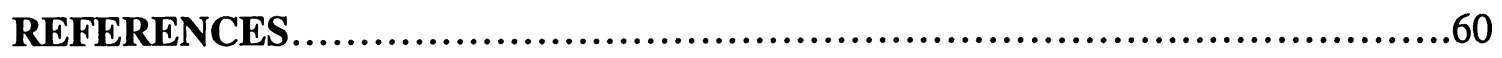

APPENDIX: Prototype web-pages printout....................................63 


\section{List of Figures}

Fig.2.1 Activity Based Costing block diagram.................................8

Fig.2.2 Implementation of $\mathrm{ABC}$ in manufacturing...........................18

Fig.2.3 Proposed hierarchy of overhead allocation to products...................21

Fig.2.4 Hypothesis of process modeling...................................23

Fig.3.1 PCA plant operation.............................................

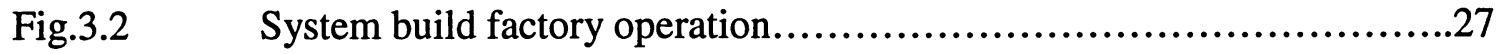

Fig.3.3 Laboratory functions.........................................27

Fig.3.4 Project architecture diagram.......................................31

Fig.4.1 JSP page translation and processing phases...........................35

Fig.4.2 Plant manufacturing activities......................................39

Fig.4.3 Proposed organization chart to record cost flow of the activities..........47

Fig.5.1 Variation between estimated cost and actual cost.......................53

Fig.5.2 Hydro cost variation..............................................55

Fig.5.3 External resource variation........................................5 


\section{List of Tables}

Table 2.1 $\mathrm{ABC}$ implementation failure - interview with managers..................13

Table 2.2 ABC implementation failure - group interview..........................14

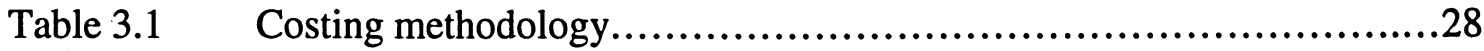

Table $4.1 \quad$ Resource cost details...............................................42

Table $4.2 \quad$ Equipment depreciation...........................................43

Table 5.1 Estimated resources and actual resources data sheet.....................51

Table 5.2 Customer order estimated cost and actual cost..........................52

Table $5.3 \quad$ Hydro cost variation data...........................................54

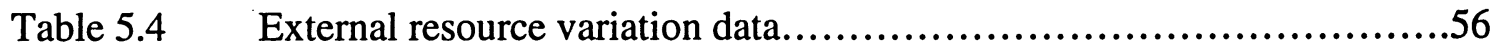




\section{Glossary}

\begin{tabular}{|l|l|}
\hline ABC & Activity Based Costing \\
\hline ABM & Activity Based Management \\
\hline AHP & Analytical Hierarch Process \\
\hline AOI & Automated Optical Inspection \\
\hline AXI & Automated X-ray Inspection \\
\hline BGA & Ball Grid Array \\
\hline CI & Continuous Improvement \\
\hline CIM & Computer Integrated Manufacturing \\
\hline CMS & Cost Management System \\
\hline EDP & Electronic Data Processing \\
\hline EMS & Electronics Manufacturing Services \\
\hline FMS & Flexible Manufacturing System \\
\hline FT & Functional Test \\
\hline GAAP & Generally Accepted Accounting Principles \\
\hline HTML & Hyper Text Mark-up Language \\
\hline ICT & In Circuit Test \\
\hline ISO & International Organization for Standardisation \\
\hline JIT & Just In Time \\
\hline JSP & Java Server Pages \\
\hline ME & Mechanical Engineer \\
\hline MS SQL & Microsoft Structured Query Language \\
\hline OEM & Original Equipment Manufactures \\
\hline PCB & Printed Circuit Board \\
\hline QE & Quality Engineer \\
\hline SMT & Surface Mount Technology \\
\hline TE & Test Engineer \\
\hline TQM & Total Quality Management \\
\hline
\end{tabular}




\section{CHAPTER 1}

\section{INTRODUCTION}

\subsection{Motivation}

Today, most companies use traditional costing methods to estimate product cost using Microsoft spread sheets. Usually, there is a difference between the estimated cost and the actual cost spent at the shop floor and on administration purposes. Increasingly, global competitiveness has forced organizations in the manufacturing sectors to produce highquality products quicker and at a competitive cost. So, it is essential for an organization to develop an information system that will provide operational cost details. Through collaboration with Celestica, a global company, the author has been motivated to develop a web-based cost management tool.

The goal of this project is to create a web-based cost management tool prototype using Temporal-ABC ${ }^{\circledR}$.

The cost management tool prototype will consist of three modules:

i) to estimate the product cost,

ii) to account for the actual manufacturing cost and

iii) to track both costs. 


\subsection{Research Goals and the Author's Contribution}

From the perspective of the enterprise's products, an enterprise's activities and its resources are not easy to identify. Also, today's manufacturing processes are subject to change for continuous improvement (CI). The main objective of this research is to develop an efficient web-based cost management tool prototype for effective cost control. The research goals are described as follows:

- Modeling the activities of an organization

- Classifying production activities

- Creating a generic resource template to match all activities

- Automating the estimation process

- Providing estimation information to shop floor people

- Capturing the actual costs

- Helping the user to track costs

- Creating a cost database

\subsection{Research Project Organization}

The main objective of this research is to propose and develop a web-based cost management tool using Temporal-ABC principles. The report is organized as follows:

Chapter 2 starts with theoretical and practical case studies background, briefly explaining the costing methodologies and the Activity Based costing implementation issues. The case studies were conducted at organizations 
throughout Europe and North America. A detailed survey of some existing ABC implementation problems and options to overcome these problems with generic strategies are presented in this chapter.

Chapter 3 is a study of the company in which the author conducted the research. The existing costing system and the procedures to estimate product cost and manufacturing technologies are described in detail in this chapter.

Chapter 4 proposes a web-based cost management tool prototype to solve the existing costing problems and to automate the estimation process. This chapter also discusses in detail the creation of the costing software using Java, JSP and MS SQL server. The prototype consists of three modules: estimation, actual manufacturing cost and tracking to manage the costs effectively. Also, the procedures to use this model are described in this chapter.

Chapter 5 presents the results and a discussion on estimation, actual manufacturing cost entries and tracking procedures.

Chapter 6 summarizes the important contributions and results in the proposed web-based cost management tool and describes future work related to this research. 


\section{CHAPTER 2}

\section{BACKGROUND}

This chapter starts with an overview of the current costing systems used by organizations and then gives a brief introduction to Activity based Costing and Temporal-Activity Based Costing (Temporal-ABC ${ }^{\circledR}$ ). It also provides a survey of some of the existing costing problems and discusses $\mathrm{ABC}$ implementation issues. The last section discusses strategies to make a costing framework based on the company's requirements.

\subsection{Traditional Costing Systems: An Overview}

Costing [Staubus 71] is the process of determining the cost of doing something, e.g., the cost of manufacturing a product, rendering a service, or performing a function which is known as the object of costing. The set of possible objects of costing is enormous depending upon the business and type of organization.

The traditional cost systems [Tham 99] use volume driven allocation bases such as direct labour hours, direct machine hours, direct labour dollars, direct material dollars, and sales dollars as the primary means of assigning organizational expenses and overheads to individual products, services and customers. However, many of the resource demands by individual products and customers are not proportional to the volume of units produced or sold. Thus, traditional cost systems do not measure accurately the costs of resources used to design, to produce, to sell and to deliver products to customers. 
Traditional costing methods were designed primarily to satisfy the need for inventory valuation as defined by GAAP (Generally Accepted Accounting Principles) in manufacturing organizations. The objectives of traditional or conventional cost accounting systems are to provide historical cost information to government regulatory agencies and tax bureaus.

The traditional cost systems may have proved adequate for providing products or costs, when the overhead costs of indirect activities were a small percentage relative to the direct labour consumed by the products. So, costing problems arise in the traditional costing system.

Also, traditional costing systems can be barriers to continuous improvement. How the Activity Based Costing approach can help overcome this will be discussed in the next section.

\subsection{Activity Based Costing}

Professors Cooper and Kaplan [Cooper \& Kaplan 92] of the Harvard Business School have developed an approach to product or service costing called "Activity-Based Costing" as a means to overcoming some of the problems of traditional costing systems.

ABC's [Tham 99] basis premise is that a company's output, such as products and services, gives rise to the need for operating, management, and administrative activities, which, in turn, necessitate that costs be incurred in providing those activities. $A B C$ 
should be viewed as a concept around which a company can construct an economic model of its business that will provide the accurate and relevant cost information necessary to support sound business decisions of all types.

This definition [Hicks 99] contains five critical points that must be understood if $A B C$ is to have business utility at all types and sizes of organizations. These five points are:

- Activity-based costing is a concept of assigning cost to activities

- It serves as a basis for an economic model

- Cost information must be accurate, relevant

- It identifies the cost of activities and the reason those activities are undertaken

- Cost information must support all types of management decisions

The traditional cost accounting [Tham 99] allocates costs to products based on the attributes of a single unit of a cost object, a typical attribute being the number of direct labour hours expended to manufacture the unit. Allocations therefore vary directly with the number of units produced. In contrast, $A B C$ focuses on the activities required to produce each product or to provide each service, based on activities consumed by the product or service.

The $\mathrm{ABC}$ concept of directing resource costs to activities (referred to as resource cost assignment) and the assignment of costs to cost objects based on their use of activities (referred to as activity cost assignment), is intuitively more appealing to deriving costs of products effectively, efficiently and accurately . 


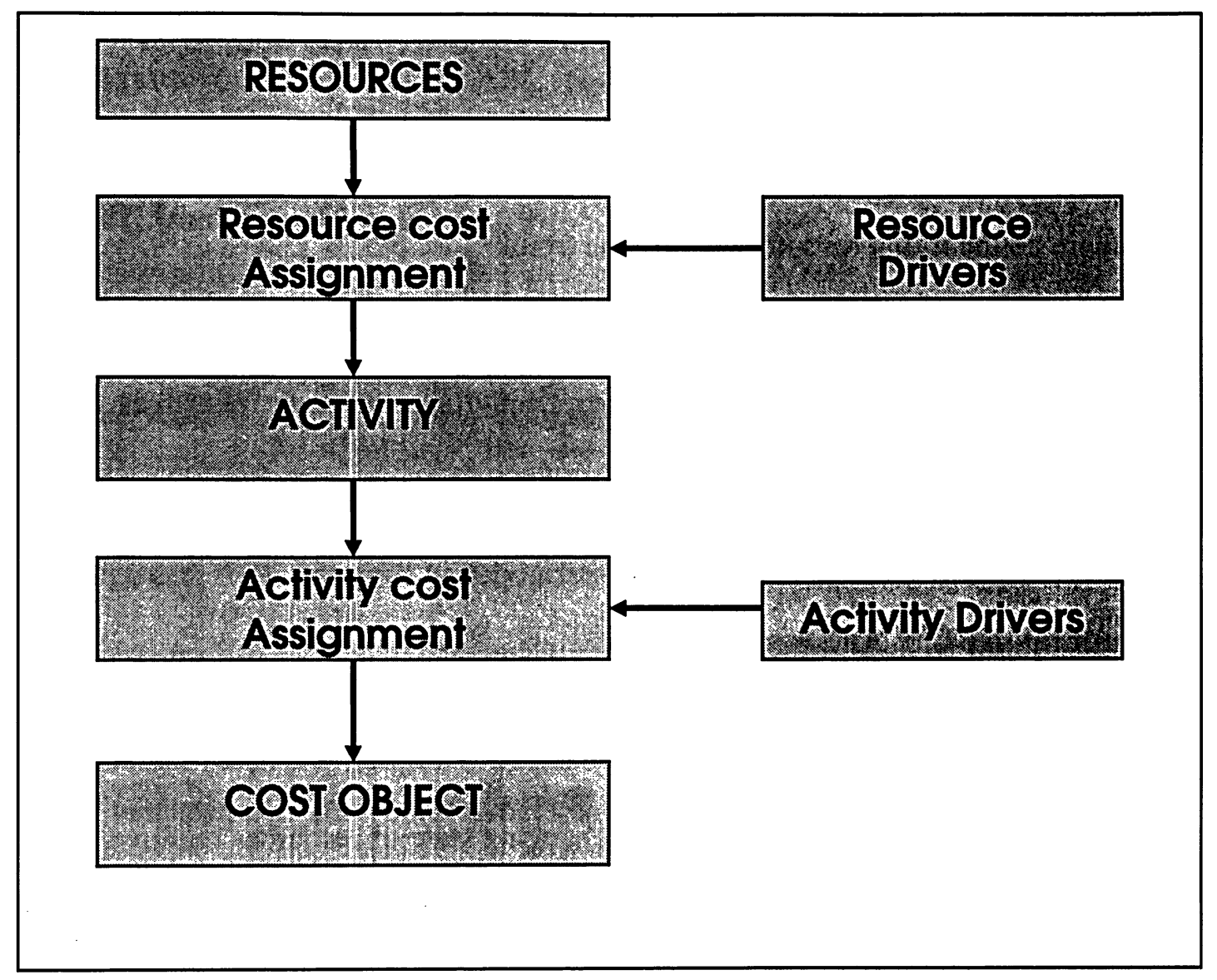

Fig.2.1. Activity Based Costing Block Diagram adopted from [Tham 99, p.106]

Fig.2.1. illustrates the ABC's methodology. In the first stage, the cost assignment of resources to an activity is accomplished through a resource cost assignment phase through "resource drivers". In the second stage, the cost assignment of activities to cost objects is accomplished through "activity drivers". A resource driver is a measure of an activity's resource consumption. An activity driver is a factor used to assign cost from an activity to a cost object. Activity drivers are the mechanisms for assigning the costs of activities to products. 
Since $\mathrm{ABC}$ assigns costs to activities based on its use of resources, there must be known or identifiable resource costs associated with each activity.

Problems with the premise:

- Where do the initial resource costs come from?

- How does one deduce the direct, indirect and overhead costs for a resource?

So, organizations must able to split enterprise activities and their resources before implementing the $\mathrm{ABC}$.

\subsubsection{Temporal- $\mathbf{A B C}^{\circledR}$ : An Overview}

The Temporal [Tham \& Fox 04] Activity-Based Costing principle includes the assignment of costs to activities based on the changing state of resources required by the activities, and the assignment of costs to cost objects (products or services). The state of resources is committed, enabled, disenabled and re-enabled (i.e., enabled again). For this research project, based upon the data provided by Celestica Inc., only the enabled resource state is used to prototype the cost system to calculate the product cost.

\section{Principle of Temporal Activity-Based Costing States:}

- A cost object (product or service) is the reason why activities are performed.

- The assignment of costs to activities is based upon their resource requirements and the possibly changing temporal states of those resources, thereby resulting in temporal costs for activities. 
- The cost of a cost object is based upon the temporal costs of activities that produce it.

The next section will discuss the $\mathrm{ABC}$ implementation issues.

\subsection{ABC Implementation Issues}

When reading through research papers that discuss $A B C$ implementation, it is concluded that the $\mathrm{ABC}$ concept has been extensively and positively accepted by all sectors of industries such as manufacturing, commercial, food processing, retail, energy, finance and logistics. $\mathrm{ABC}$ has been widely accepted to provide accurate cost information to the organization. However, when replacing the existing costing system with the new costing system, the organizations face many implementation problems that arise from all levels of the management. Many researcher conducted studies about the implementation issues and how to over come the failures, which are discussed below.

\subsubsection{ABC Implementation Failure}

Most of the activity-based costing systems introduced in recent years are said to fail. Teemu Malmi [Malmi 97] analysed the reasons behind the failures to implement ABC. The implementation resistance in accounting and manufacturing is considered the main reasons for the failures.

Teemu further describe the $\mathrm{ABC}$ serving strategy as: "My conception was that we did not necessarily know which products and volumes the money came from. And that is exactly what I wanted to know before deciding on how to develop that particular business 
strategically. This is what we were thinking of; we did not have any true knowledge about that".

The study proposed a framework to assist the $\mathrm{ABC}$ implementation process. The case study also attempted to illustrate the diverse origins of resistance. The company's economic reasoning to resist the new system is because it did not help them in running the day-to-day operations of the factory and because they were able to diversify basically the same information from other sources. Teemu pointed out that, presenting these single cases in two parts highlighted the diverse interests of organizational stakeholders. The conception of a single $\mathrm{ABC}$ project's success may depend on stakeholders, even without allowing for political sentiments. The management group used $\mathrm{ABC}$ successfully for their strategic purposes, whereas local management was comfortable with the informal estimates and did not regard the new system as valuable for their day-to-day management of the factory. Consequently, for local management, the $\mathrm{ABC}$ system was a failure.

Overall, the failure was due to the resistance created by local management. Discussing the employee's problem to execute each activity can rectify this; the resistance can be reported to top management for possible solutions.

According to McNair [Waeytens \& Bruggeman 94] continuous improvement is “...an incremental change process that focuses on performing existing tasks more effectively: small improvements are made in the status quo as a result of ongoing efforts. In a continuous improvement environment, every individual, whether in the management 
or on the shop floor, assumes responsibility for the quality, timeliness, efficiency, and effectiveness of the productive process."

$\mathrm{ABC}$ has been recommended as an appropriate tool for guiding and directing the process of improvement through the use of Activity Based Management (ABM). Though ABC is good for continuous improvement and improved costing systems, many companies failed to implement $\mathrm{ABC}$ successfully. Included below are the barriers behind the successful implementation of $\mathrm{ABC}$.

There are many cost management software installed in companies. John Miller [Waeytens \& Bruggeman 94] further states that, “...a Cost Management System, by itself, produces no increase in productivity, no reduction in cycle time, and no increase in customer satisfaction. Its true benefit can be measured only in the light of management's actions initiated based on information provided by the new CMS. Those actions should be directed toward continuously improving the organization's activities and business processes through better decision making".

The ABC system helps management to make better decisions. However, to formulate an enterprise's activities and resources, an $\mathrm{ABC}$ professional faces various problems. Dominique Waeytens's detailed research will elaborate the problems and their reasons.

The research was conducted by a Belgian company, which manufactures textile machinery. The company lost money due to spare parts that were covered by warranty 
periods and felt that the current costing system, which used machine hours as a major overhead allocation base, did not correctly reflect the products' use of overhead resource categories such as purchasing, marketing and sales, technical customer support and warehousing. So, they got interested and started an $\mathrm{ABC}$ project. Though the company hired a top $\mathrm{ABC}$ consultant to implement the new costing system, the company reported, after 18 months that they could not implement ABC successfully.

So the company hired professors from top universities and interviewed 21managers at the company. The following questions were asked of the manager:

- How were you involved in the $\mathrm{ABC}$ project?

- How were you informed about the results of the $\mathrm{ABC}$ project?

- What did the $\mathrm{ABC}$ project reveal? What was the importance of the $\mathrm{ABC}$ project for your department?

- How were you asked to detect cost reduction and improvement initiatives?

- Did you formulate cost reduction initiatives?

- No: Why not?

- Yes: Which? How did you formulate these initiatives? Did you use the ABC model?

- Do you believe in the ability of the $\mathrm{ABC}$ study to make processes more efficient? What about $\mathrm{ABC}$ in general?

- Do you feel any lack of information to manage your department effectively? 
The interview queries and answers are listed in Table 2.1. to describe more about the shortcoming of $\mathrm{ABC}$ implementations.

\begin{tabular}{|c|c|}
\hline Interviewee & Shortcoming of $A B C$ \\
\hline $\begin{array}{l}\text { Administrator of material } \\
\text { management }\end{array}$ & Too complex and the activities are badly defined \\
\hline Quality Manager & We cannot see the effect of our actions on the costs. \\
\hline EDP Administrator & $\begin{array}{l}\text { We do not see the link to other programs like ISO } \\
9001 . \\
\text { There are too many details and too much focus on } \\
\text { production, complex calculation. }\end{array}$ \\
\hline Production Manager & Would create a revolutionary change in the company. \\
\hline Personnel Manager & $\begin{array}{l}\text { Our activities are very diverse and change over time } \\
\text { We don't have standard time for certain activities. }\end{array}$ \\
\hline $\begin{array}{l}\text { Technical Manager } \\
\text { Purchasing Manager }\end{array}$ & $\begin{array}{l}\text { You cannot implement } \mathrm{ABC} \text { just by telling the people } \\
\text { to do an activity analysis. }\end{array}$ \\
\hline $\begin{array}{l}\text { One production cell } \\
\text { Manager }\end{array}$ & Market situation doesn't permit for strict timing. \\
\hline
\end{tabular}

Table 2.1: $A B C$ implementation failure- interview with managers

Table 2.2 outlines the reasons why managers could not come to improvement initiatives based on $\mathrm{ABC}$. 


\begin{tabular}{|l|l|}
\hline \multicolumn{1}{|c|}{ Interviewees } & \multicolumn{1}{c|}{ Motivation } \\
\hline $\begin{array}{l}\text { Administrator of material } \\
\text { management, Sales, } \\
\text { Technical and Personnel } \\
\text { Manager }\end{array}$ & $\begin{array}{l}\text { Top management did not consider this a priority. We } \\
\text { were not explicitly asked and we were not motivated } \\
\text { to do it. }\end{array}$ \\
$\begin{array}{l}\text { Customer support, EDP, } \\
\text { Mouldry Manager } \\
\begin{array}{l}\text { Quality, Purchasing, EDP } \\
\text { and Material Manager } \\
\text { Quality and EDP Manager } \\
\text { Marketing and Mouldry } \\
\text { Manager }\end{array}\end{array}$ & $\begin{array}{l}\text { We are already involved in several other projects such } \\
\text { as the ISO 9001 program. } \\
\text { We already lost people last year; we cannot cut down } \\
\text { on people again! } \\
\text { We cannot influence our costs in the short run. } \\
\text { Accountant Manager }\end{array}$ \\
$\begin{array}{l}\text { We cannot really manage our department and we do } \\
\text { not have the freedom or the power to manage } \\
\text { resources flexibly. } \\
\text { Our department is too small to find any significant } \\
\text { improvement. }\end{array}$ \\
\hline
\end{tabular}

Table 2.2: ABC implementation failure- group interview

When analysing the problem in detail, the following causes and failures became evident:

- Causes related to $\mathrm{ABC}$ design

- Causes related to organization environmental characteristics

- Causes related to management control system

- Causes due to employees routine work

- Causes due to employees unwillingness to accept new system 
Before starting $\mathrm{ABC}$ implementation, the organization should conduct employee training that outlines its benefits for both the company and the individual.

Ron Eden [Eden \& Maingot 02] had conducted Activity Based Costing implementation in Canadian High tech industries. Though companies criticize traditional volume-based cost models related to firm understands of product and customer profitability, $\mathrm{ABC}$ concepts still have not been accepted by all of the companies.

The objective is to study the barriers to successful adoption of $A B C$ by all organizations. The research, conducted in August 2001, and basic questions were mailed to 50 high tech companies located in the Ottawa area.

The questions were framed to measure the accuracy of the current data, differences in product demands on resources, involvement of staff in assessments, and the impact of $\mathrm{ABC}$ on cost and resource allocation problems.

The responses received illustrated that none of the companies rejected the $\mathrm{ABC}$ concept and the usage of $\mathrm{ABC}$ is restricted only to particular section of the company.

$75 \%$ of the companies believed that $\mathrm{ABC}$ could provide cost accuracy and assess resource demands for products. The study shows that $\mathrm{ABC}$ is not a domain for accountants. 
The survey suggests a low rate of adoption of $A B C$ in high technology companies. It declares that the firms have a high rate of product and process redesign. Also, the author suggests $A B C$ training to all staff members.

\subsubsection{ABC Implementation Success Strategies}

A. Gunasekaran [Gunasekaran \& Sarhadi 98] discusses the implementation issues of Activity Based Costing $\mathrm{ABC}$ in manufacturing. The strategy to improve productivity and quality with a reduction of cost is discussed. In general, a framework to implement $\mathrm{ABC}$ in manufacturing has been prepared.

The various costing method to increase the accuracy of product cost, product mix, pricing and other investment decision-making are analyzed and the introduction of $\mathrm{ABC}$ is justified.

The advanced manufacturing techniques such as JIT, FMS, CIM, TQM and Kaizen should be considered before implementing ABC. Therefore, the ABC system follows cost allocation based on unit level bases, batch-level bases, product level bases and facility level bases. The possible implementation issues are predicted by the author as a lack of a suitable practical framework, an alignment between business and manufacturing strategies and the role of $\mathrm{ABC}$, unavailability of a structured approach to analyse and continually improve the fundamental activities, neglect of behavioural and managerial issues and a lack of attention to the user-friendly $\mathrm{ABC}$ system in practical issues. 
The implementation issues are discussed with five case studies conducted in the following industries: metal, food and sweet producing, pharmaceuticals and plastics. The study reveals the following practical issues:

- Identification of cost objects

- Allocation of costs based on the resources consumed

- Identification of major critical activities

- Analysis of the activities based on different resources consumed

- Selection of appropriate cost drivers

- Selection of appropriate overhead cost allocation

- Select areas where improvement is needed

- Identify major factors for $\mathrm{ABC}$ analysis

- Educate and train the worker in new cost management selection

- Offer suitable incentives to employee for learning the new cost management system

- Support the company's corporate strategy such as flexibility, productivity and quality

- Identify suitable policy for transfer pricing

From a review of the case studies, a framework has been made to implement $A B C$ in manufacturing which deals with the integration of the system with the existing system, precision of the system, system reports historical or future costs, and initial decision of the system. 


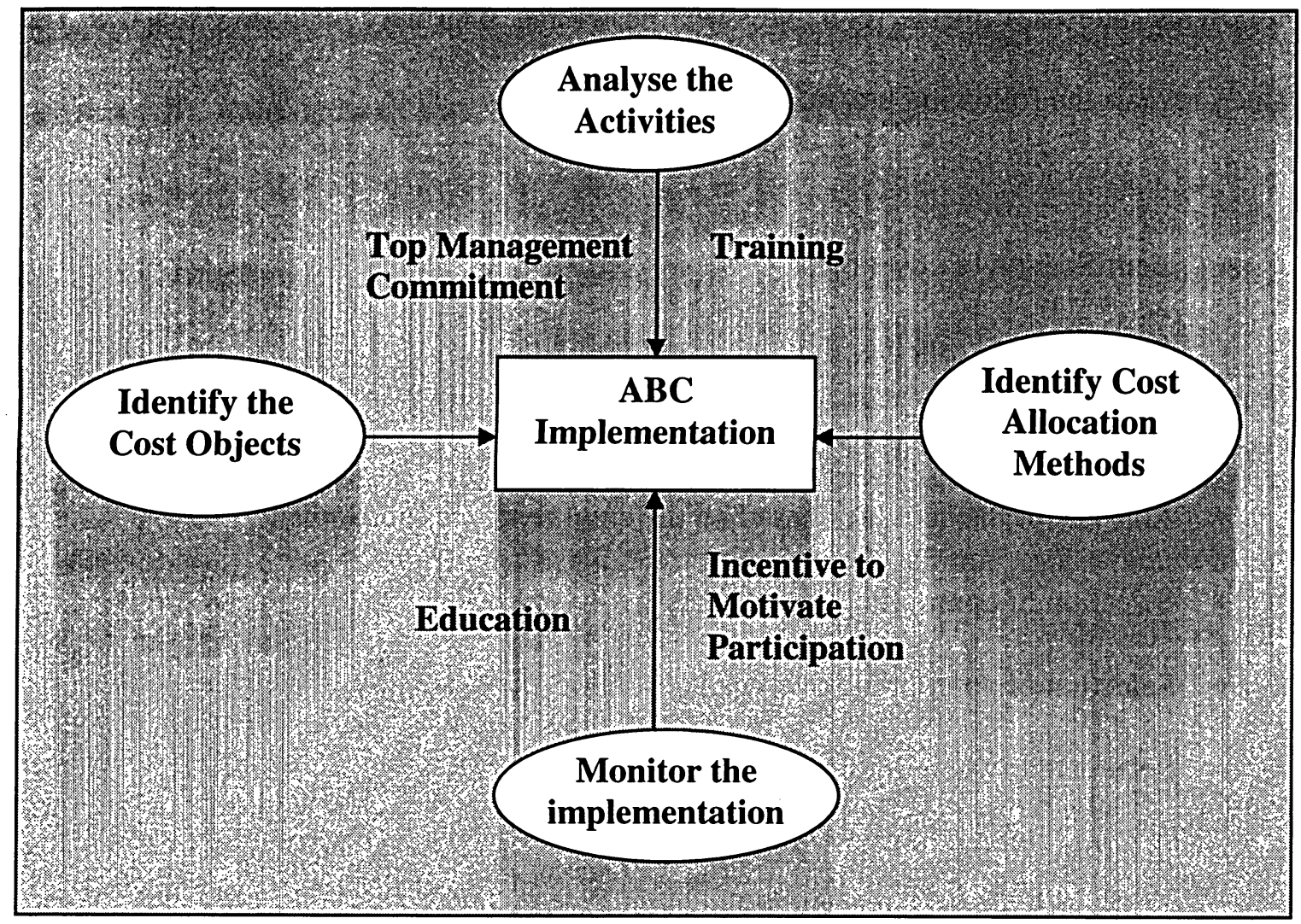

Fig.2.2. Implementation of $A B C$ in manufacturing [Source Gunasekaran \& Sarhadi 98]

The research provided a generic $\mathrm{ABC}$ implementation strategy and is illustrated in

Fig.2.2. ABC implementation analyse the activities, identify cost allocation methods, identify the cost object and monitor the implementation. It also demands top management commitment, training, education and incentives.

Vidya N. Awasthi [Awasthi 94] discusses the resistance and change process when implementing $\mathrm{ABC}$. Also, the author suggests a framework to overcome the resistances in stages such as the model-data gathering, information sharing, action planning and implementation and feedback. The main factors involved in the changing process are: 
customer demands, changes in manufacturing and distribution technology, global competition, narrow margin of error and change in information technology.

The resistance to change during the implementing stage is considered at the individual and organizational level. The individual resistances are: economic reasons, habit, dependence on supervisors, and fear of uncertainty and selection perception. The possible resistances at the organizational level are threats to power, organizational structure and hierarchy, resource limitation, fixed investments and inter-organizational agreements.

The research of Awasthi [Awasthi 94] provides the resistances; how implementation engineers should overcome the resistances is also explained.

Fariborz Y. Partovi [Partovi 91] expresses "apparently Activity-Based Costing taken cost management by storm". This paper proposes an estimating model to allocate overhead costs to different products. Based on the research with traditional costing and $\mathrm{ABC}$ the author prepared a framework by integrating $\mathrm{ABC}$ and Saaty's Analytical Hierarchy Process (AHP) to allocate overhead cost to products.

The first stage of the framework allocates total overhead costs to the plant's major activities using $\mathrm{ABC}$. The second stage allocates the overhead cost driver to product. The cost allocation varies from product to product.

Fig.2.3 framework has been tested in Ace Inc., manufacturer of computers and telephone wire and cable. The main products of the company are 20 gauge, 22 gauge and 24 gauge cable. The raw material alone takes $65 \%$ of the product's cost. So the company forfeited more attention while allocating the overhead cost to the products. The cost allocation is 
done in three stages to allocate cost to the activities. The major plant activities are maintenance, supervision, material handling, tools and dies and quality control. The second stage allocates overhead cost from the activities. to different products. The allocation of cost to different products based on complexity of the product, the volume of raw materials going into the product, and the overall throughout time cost drivers.

The AHP allocate overhead cost by considering the historical data. The cost drivers are weighted in percentages. Finally, all the activities' overhead cost is integrated to find out the final overhead cost. 


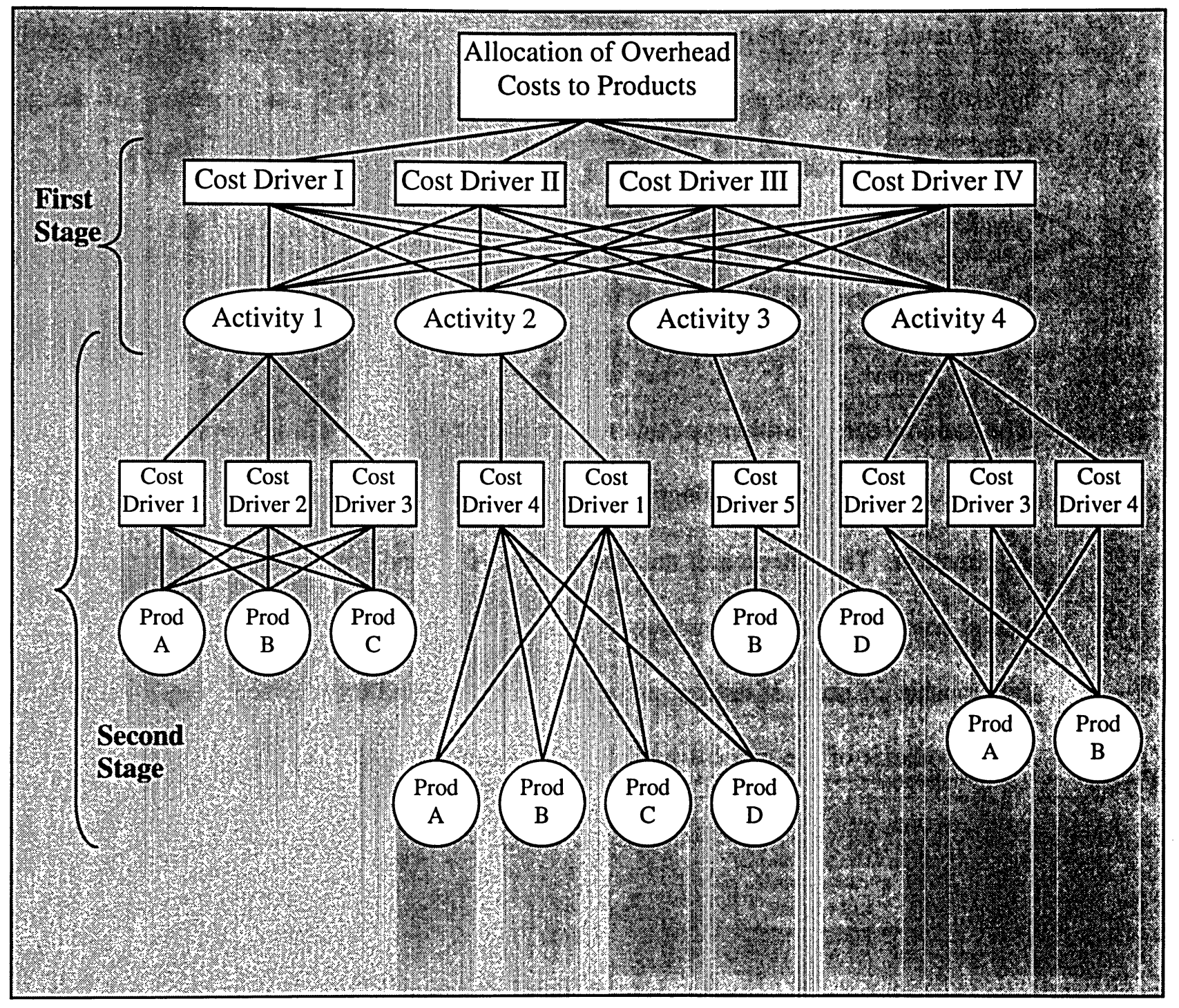

Fig.2.3. Proposed hierarchy of overhead allocation to products [Source Partovi 91]

Though the above method tested at Ace Inc., the hierarchy combined with ABC and AHP could not be implemented. Management has discovered the advantage of allocating accurate overhead cost. 
Katja Tornberg [Tornberg et al. 02] supports the Activity Based Costing system and reiterates the necessity to consider $\mathrm{ABC}$ during the product's design stage. This study investigate the possibilities of Activity Based Costing and the modeling of design, purchasing and manufacturing process in providing useful cost information for product design. The result emphasizes cost-conscious design and motivates the relationships between the activities performed in the organization and their associated costs.

The main research problems of this research are: the need to manage costs efficiently, the critical role of product design in cost management and the lack of relevant cost information. The outcome of the study is that $\mathrm{ABC}$ and process modeling could provide useful cost information for product design. The process modelling reiterates the effective relationship of product design, production planning and management. Fig.2.4 illustrates the hypothesis of the process modeling. The combined $\mathrm{ABC}$ and process modeling cost calculations reveal the effects of different design options at the product design. 


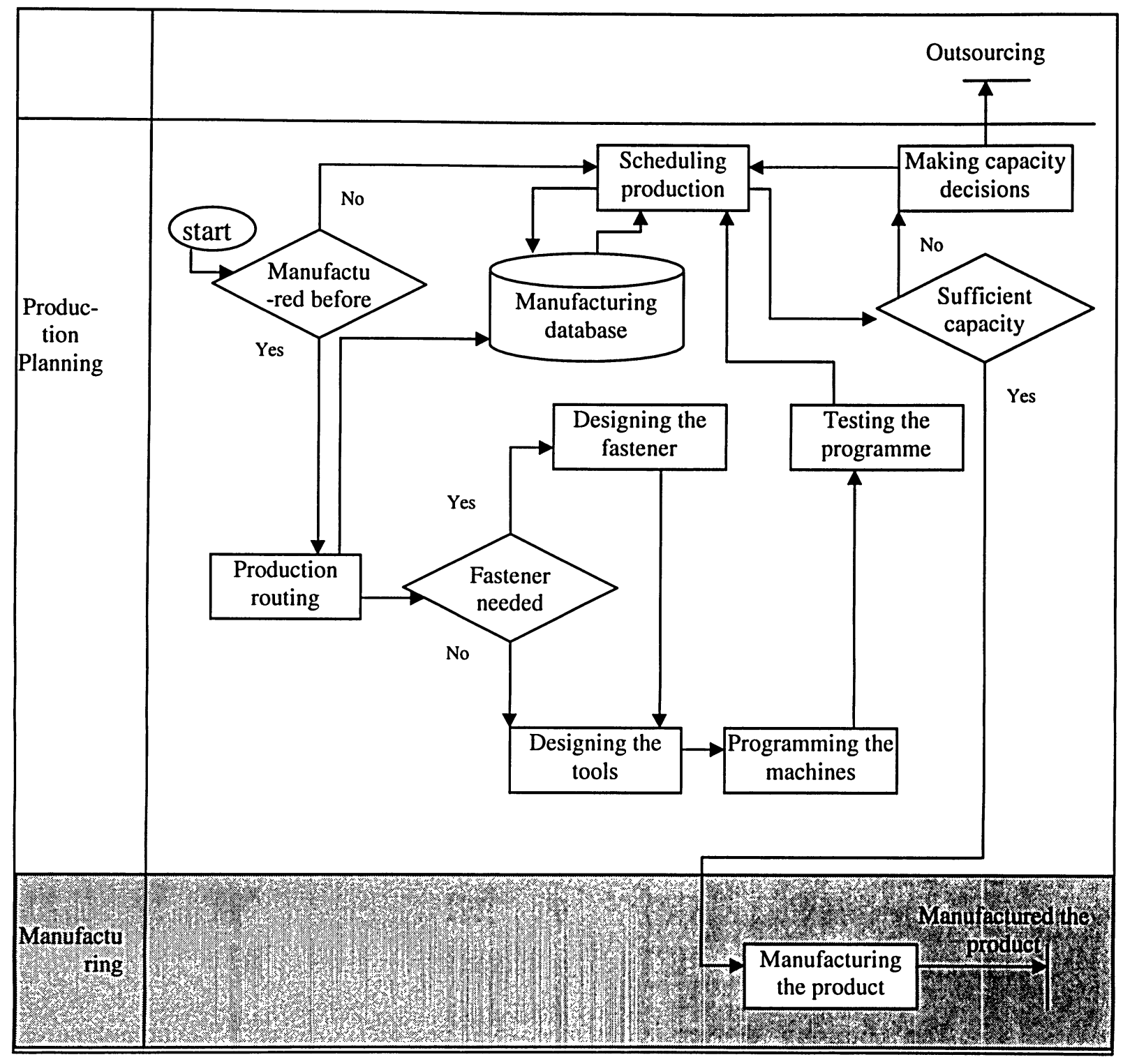

Fig.2.4. Hypothesis of process modeling 


\section{CHAPTER 3}

\section{COMPANY ANALYSIS: CELESTICA INC.}

\subsection{Introduction}

The research is conducted through discussions with the cost engineer and overview of the manufacturing plant. Celestica Incorporated is a world leader in the delivery of innovative electronics manufacturing services (EMS). Celestica operates a highly sophisticated global manufacturing network with operations in Asia, Europe and the Americas, providing a broad range of integrated services to leading original equipment manufacturers (OEMs) across a variety of industries.

The Toronto plant operates on a two-shift basis to manufacture different kinds of electronics products.

\subsection{Product Details}

The company delivers comprehensive product solutions, including power, memory, graphics, plastics, servers and workstations. It has plants worldwide to manufacture products based on customers for a wide variety of customers with a wide range of complexity.

Celestica has implemented Six Sigma quality and Lean manufacturing to improve operations and cost-competitiveness. 


\subsection{Process Details}

Celestica manufactures Printed Circuit Boards (PCBs) based on Surface Mount Technology (SMT) operation. The operations that observed at the Toronto PCA-build factory are illustrated in Fig.3.1 The raw board is passed from Screener to the high-speed placement machine, high accuracy placement machine, reflow and oven to form a completed circuit board.

The test development and support team considers all aspects of testing that includes failure analysis, data management, testing cost and quality. The testing department carries out optical and x-ray inspection (AOI and AXI), as well as in -circuit test (ICT) and functional test (FT) development. 


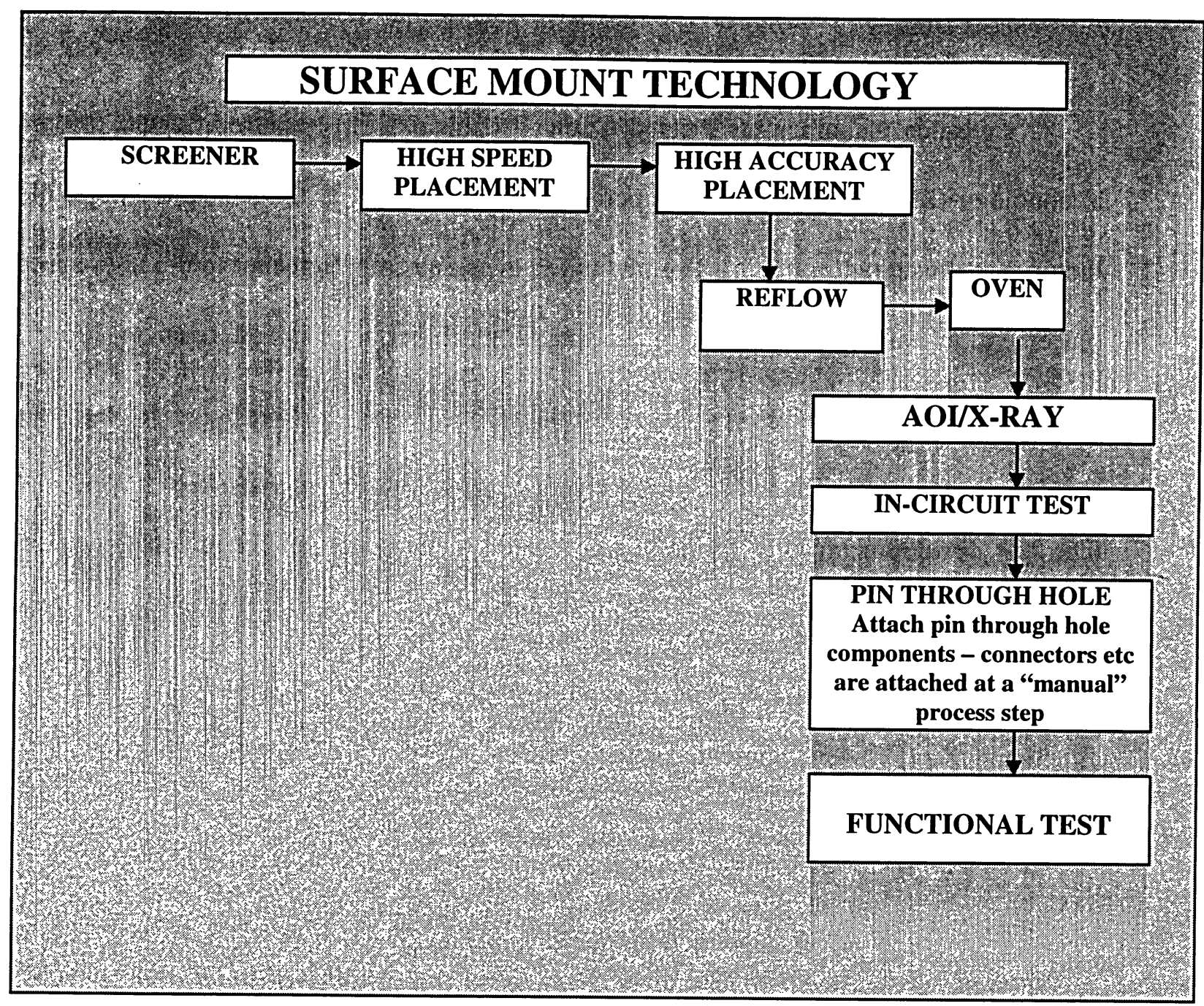

Fig.3.1. PCA plant operation

The System Build factory operations are described in Fig.3.2. The PCA boards are assembled into the cabinet; these could come from any PCA factory worldwide. Most of the operations are carried out manually. Finally, the assembled cabinets are tested in the System testing area. 


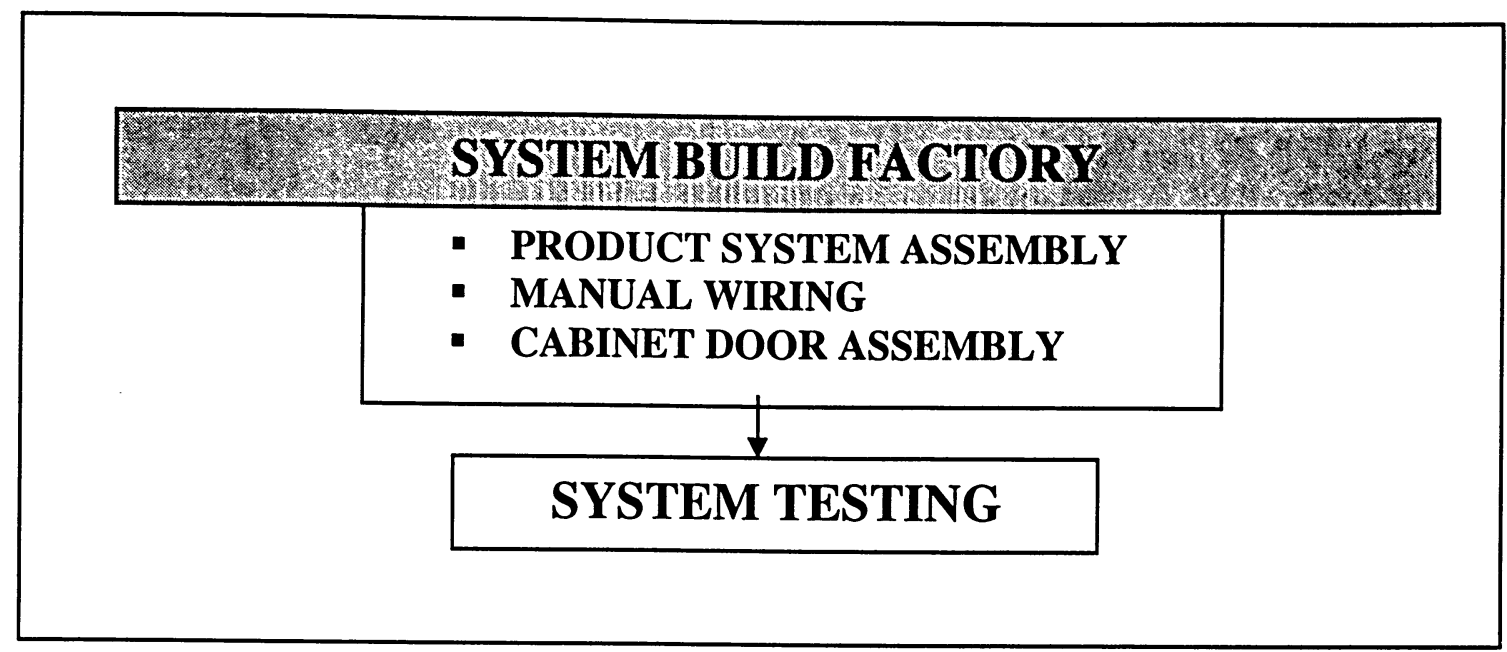

Fig.3.2. System build factory operation

Parts only go to the lab if there are symptoms of more serious issues. Regular failures detected at the test or inspection step are usually just sent to the PCA factory's repair cell. The lab has a lot of high-tech equipment and is usually only reserved when a more detailed root cause analysis is required. The lab will work with component suppliers where required. Fault analysis laboratory functions are described in Fig.3.3.

\section{FAULT ANALY YSIS LABORATORY}

- Analyse systematic failures/issues

- Rejected components testing

- Finding the root cause for failures

Fig.3.3. Fault analysis laboratory functions 


\subsection{The Existing Costing Methodology}

Table 3.1 explains the existing costing methodology: Material cost is calculated from the bill of materials (BOM). Material management such as inbound rate and outbound rate, scarp, planning and buying are considered by supply chain model. At present manufacturing cost is arrived using Traditional Costing or Traditional ABC. Selling Goods and Administration (SG\&A) costs are calculated based on the historical spending expenses.

\begin{tabular}{|l|l|}
\hline MATERIAL COST & A \\
\hline MATERIAL MANAGEMENT COST & B \\
MANAGING RATE & \\
$\quad$ ONBOUND RATE & \\
OUTBOUND RATE & \\
SCRAP & \\
BUYNING & \\
\hline MANUFACTURING & C \\
ASSEMBLY & \\
DIRECT LABOUR & \\
\multicolumn{1}{|l}{ INDIRECT LABOUR } & \\
TESTING & \\
DIRECT LABOUR \\
INDIRECT LABOUR
\end{tabular}

Table 3.1: Costing methodology 


\subsection{Problem Definition}

As discussed earlier, the company is a leader in the delivery of innovative electronics manufacturing services and it operates a highly sophisticated global manufacturing network with operations in Asia, Europe and the Americas, providing a broad range of integrated services to leading original equipment manufacturers (OEMs) across a variety of industries. The estimation process is carried out at the headquarters and the products are manufactured at different manufacturing plants around the world.

The following problems are identified in the existing estimation process:

- There appears to be a problem with tracking for the order estimated and the order manufactured at the plant.

- Microsoft spread sheet template is used for the estimation and it is a manual process.

- The present estimation system does not appear to provide specific information when needed.

- The activities assigned for the product and actual activities carried out to produce the product may vary and there seems to be no direct tracking systems available at present. 


\subsection{Proposed Solution}

The prototype will be developed to solve the above issues. Below are the proposed solutions:

- The project will be done in intranet / internet technology and provision will be given to track the order that has been estimated and actually manufactured at the plant.

- Product cost will be estimated using Temporal- $\mathrm{ABC} ®$ and the estimation process will be computerized.

- All the information and data will be stored and can be retrieved as and when needed.

- A proper cost tracking system will be provided

\subsection{Project Architecture Diagram}

The architecture below represents the use of software technologies and languages used in the project. The Fig.3.4 illustrates the Project architecture diagram. User has the access to do the three operations such as estimation, actual manufacturing entries and tracking. The Java Server Pages (JSP) is used to interact with database server to store and retrieve the data. Tomcat server is used to run JSP. The use software Java, JSP and MS SQL database are discussed in detail in next chapter. 


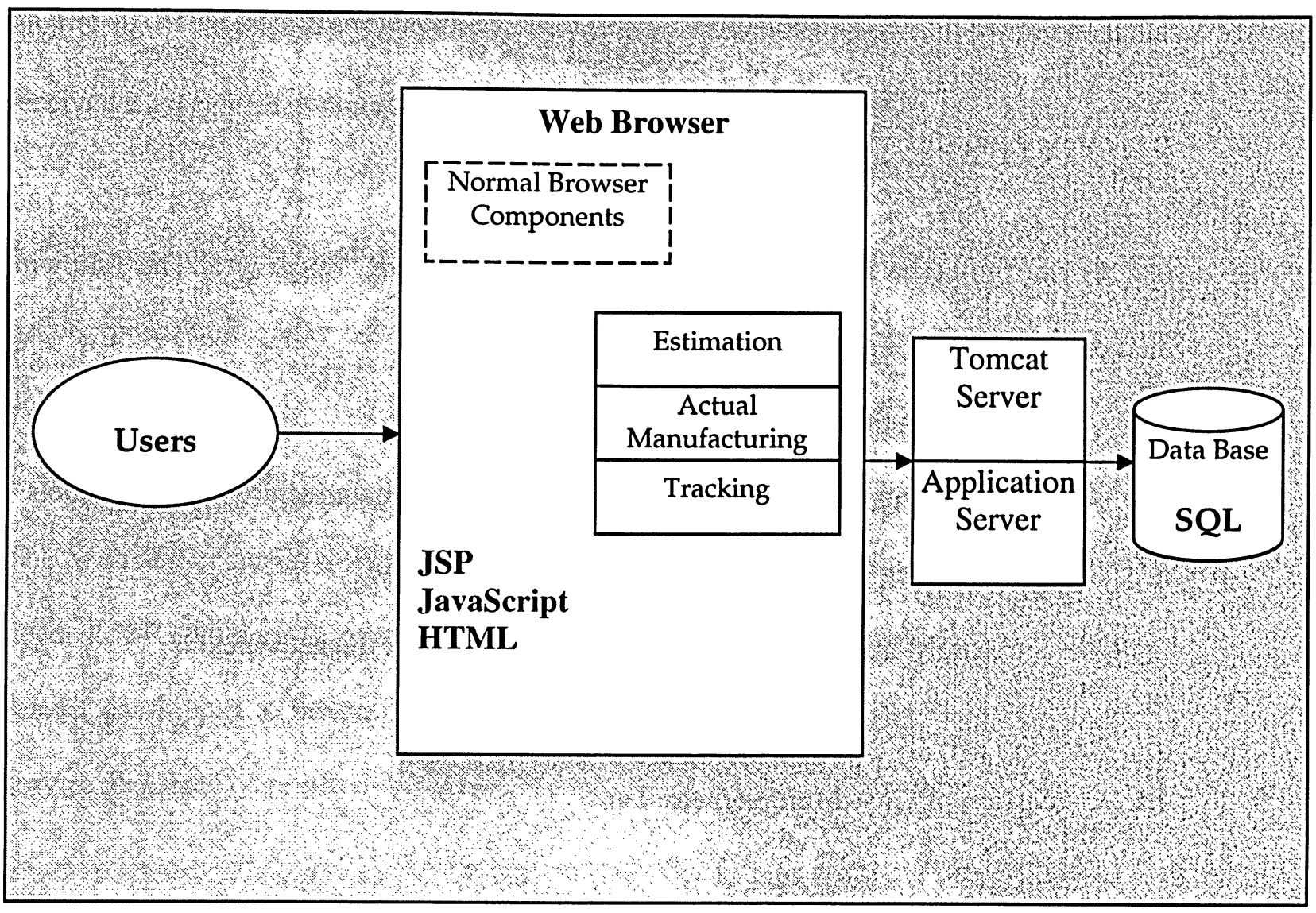

Fig.3.4 Project architecture diagram 


\section{CHAPTER 4}

\section{PROTOTYPE DEVELOPMENT}

The prototype is developed using the Temporal- $A B C^{\circledR}$ principle. The following methodologies are adopted for the development.

- Modeling the activities of an enterprise

- Classifying enterprise's production activities to manufacture all the products

- Generating the resource usage with related to time

- Creating a generic resource template to match all the activities

\subsection{Description of Cost Management Tool}

The cost management tool is developed to perform three main functions:

- Estimation of a product cost

- Actual cost spent to produce a product

- To be able to track costs

Since more than one department staff member is needed to operate the system and to capture the flow of cost, web-based technology has been chosen for the project. The prototype is developed using Java, JSP and MS SQL database server.

Java is a high-level programming language and a powerful software platform. Java Server Pages (JSP) are HTML, with additional JSP tags processed on server side, links to other Java entities for more complex processing/ database access, platform independent. 
Java Server Pages (JSP) is technology used for web application development that has received a great attention in the business world since it was released.

A JSP page cannot be sent as-is to the browser; all JSP [Bergsten, 01] elements must be first be processed by the server. Turning the JSP page into a servlet, and then executing the servlet do this.

The Web server needs a servlet container to provide an interface to servlets; the server needs a JSP container to process JSP pages. The JSP container is often implemented as a servlet configured to handle all requests for JSP pages. In fact, these two containers - a servlet container - are often combined into one package under the name web container.

A JSP container is responsible for converting the JSP page into a servlet (known as the JSP page implementation class) and compiling the servlet. These two steps form the translation phase. The JSP container automatically initiates the translation phase for a page when the first request for the page is received. The translation phase takes a bit of time, of course, so a user notices a slightly delay the first time a JSP page is requested.

The JSP container is also responsible for invoking the JSP page implementation class to process each request and generate the response called the request-processing phase. Fig.4.1 illustrates the working principle of JSP technology. The client machine's request explain.jsp is being sent to the server through the browser. The server reads the file and 
generates the java servlet file; then after it compiles and sends back to the client machine as the response to the browser.

Microsoft SQL Server is a relational database that runs on the NT operating system. SQL, Structured Query Language, is a widely accepted industry standard for defining, changing, and managing data and controlling to the database.

The following software packages are to be installed in a computer to run this prototype.

- Java Virtual Machine

[Source to download: http://java.com/en/download/index.jsp]

- Tomcat Server:]

[Source to download: http://tomcat.apache.org/download-55.cgi ]

- MS SQL Server

[Source to download:

http://www.microsoft.com/downloads/details.aspx?FamilyID=413744d1a0bc-479f-bafa-e4b278eb9147\&DisplayLang=en ]

The above-mentioned softwares are freely downloadable from the proprietor's website in accordance with their copyright policies. 


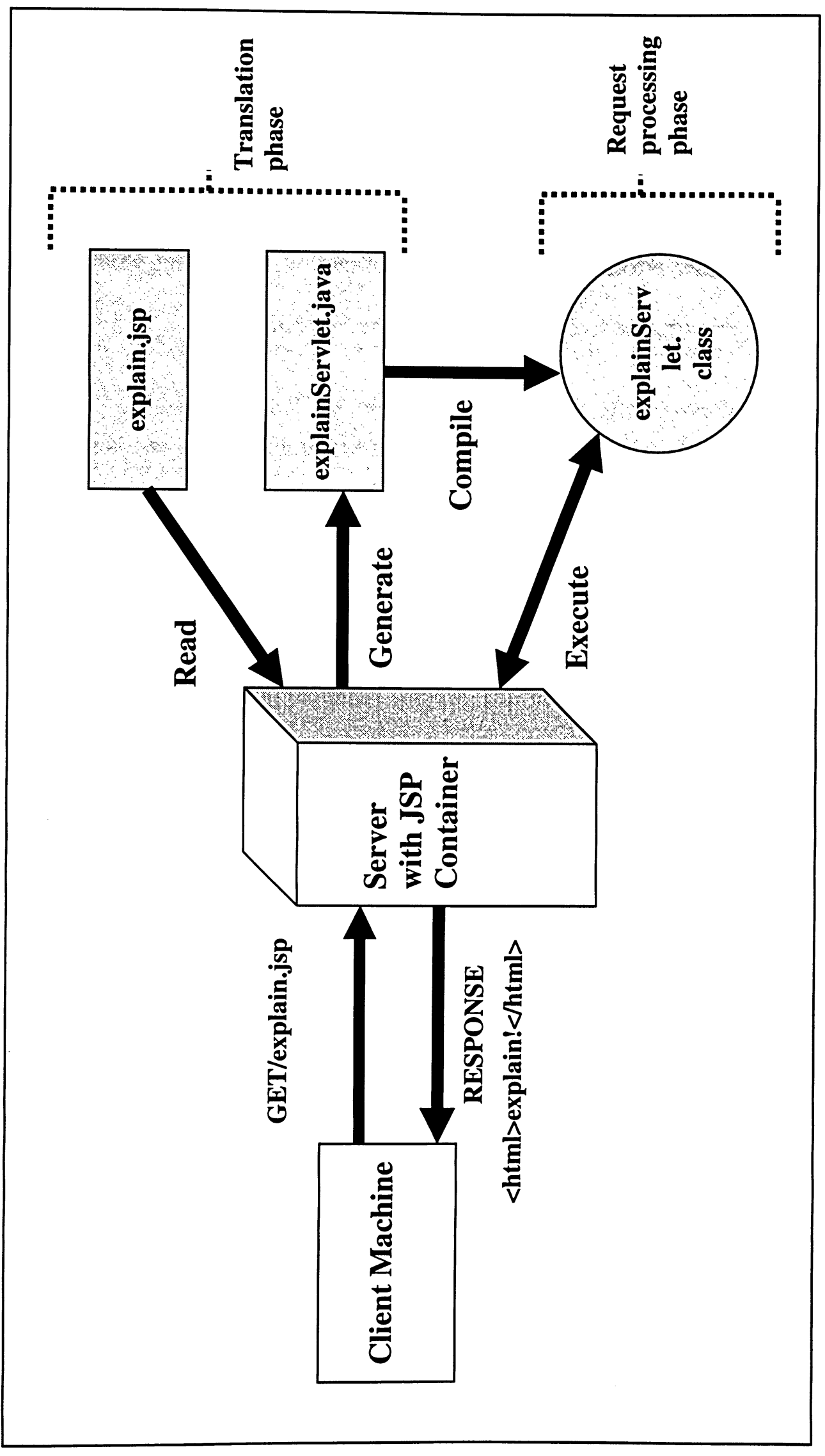

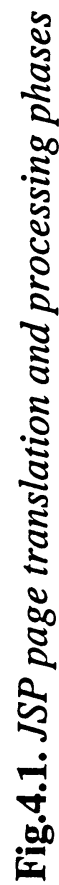




\subsection{Estimation}

Cost Estimation [Atkinson 87] is defined as predetermining the lowest realistic cost of an item or activity, which assures a normal profit. The purpose of cost estimation is to negotiate a contract price, to determine the profitability of existing products in a multi-product firm, pricing, and to determine cost of the by-product.

The scope of the research is limited only to the manufacturing activities and is shown in Fig.4.2. The following are the company's main manufacturing activities to produce different kind of products.

- Kitting - Gather all of the parts required to build the product.

- SMT Bottom Side - Surface Mount Technology bottom side operation includes all inline SMT machines: screener, placement, oven etc.

- SMT Topside - Surface Mount Technology topside operation, includes all inline SMT machines: screener, placement, oven etc.

- AOI - automated optical inspection.

- AOI Diagnostics - board that fail AOI go to this step to diagnose the failure, usually they will go through one or more of the repair steps before being returned to AOI.

- X-ray - $x$-ray to check joints under BGA's etc.

- X-ray diagnostics - board that fail $x$-ray go to this step to diagnose the failure, usually they will go through one or more of the repair steps before being returned to $x$-ray. 
- Manual - prepare \& place pin through hole components on the board.

- Wave Solder - wave-solder attach the PTH components.

- Post Solder Inspection - post-solder inspection of PTH placements.

- Press fit - press-fit connectors.

- ICT - in circuit test (bed of nails test.)

- ICT Diagnostics - boards that fail ICT go to this step to diagnose the failure, usually they will go through one or more of the repair steps before being returned to ICT.

- Mechanical Assembly - assembling screws, heat sinks.

- Manual inspection - manual inspection.

- Track - tracking step.

- Functional Test - functional test.

- Functional Test Diagnostics - boards that fail FT go to this step to diagnose the failure, usually they will go through one or more of the repair steps before being returned to FT.

- Hand Repair - different types of repair are available, not all cards would require repair, and not all cards that do require repair require all steps, it will depend on what needs to be repaired.

- Solder Fountain Repair - different types of repair are available, not all cards would require repair, and not all cards that do require repair require all steps, it will depend on what needs to be repaired. 
- BGA Repair - different types of repair are available, not all cards would require repair, and not all cards that do require repair require all steps, it will depend on what needs to be repaired.

- Pack - put the product in an ESD bag and pack into a box.

From a study of the company, it is evident that most of the activities are common for the different kind of products.

The existing estimation process considers the operator, the engineer and the floor space as major resources to determine the cost of the activities; administration and other resources are added to certain percentages based on the history of expenses.

The Temporal Activity-Based Costing [Tham \& Fox 04] principle includes the assignment of costs to activities based on the changing state of resources required by the activities, and the assignment of costs to cost objects (products or services). The state of resources is committed, enabled, disenabled and re-enabled. (i.e. enabled again).

For this research project based upon the data provided by Celestica Inc, the enabled resource state only used to prototype the cost system to calculate the product cost. 


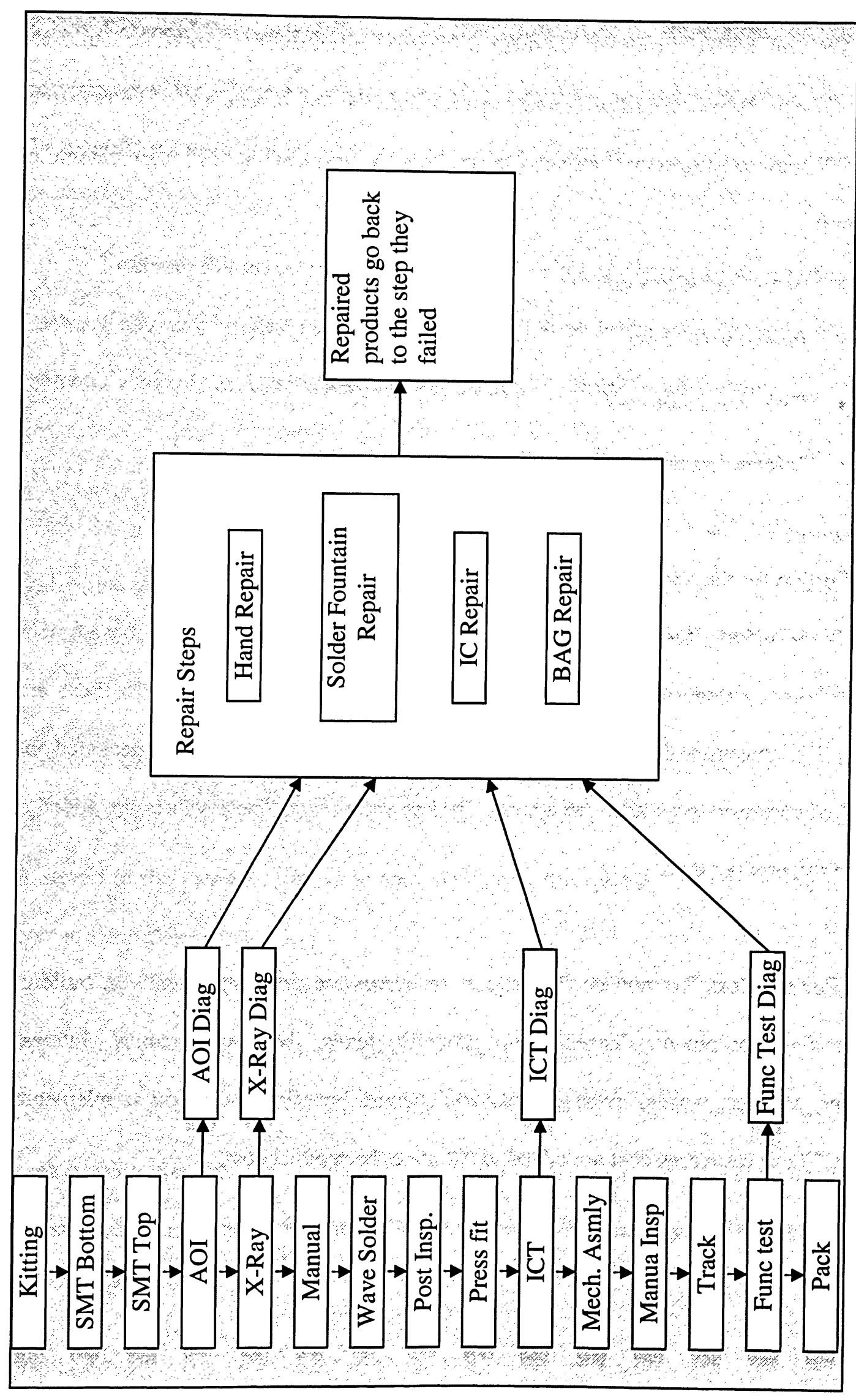

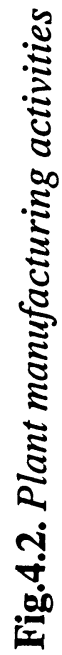


The estimation tool is designed to select activities specifically required to build the product (The prototype screen printouts are attached with the Appendix A). The resources [Tham 99] required to perform an activity are broadly classified as four main categories as follows:

- Non- Period resources

- Period resources

- External resources

- Internal resources

The definition for the above resources is described below:

Non-Period Resources: Non-period cost external resources are based upon traditional cost categories such as materials costs and utility costs (hydro, heat and water). The consumption of hydro, heat and water to an activity should be measured and the unit of consumption should be obtained before estimation. These values are added to estimate the product cost.

Period Cost Resources: Period cost resources are time dependent e.g. building depreciation, equipment depreciation, property taxes, borrowed capital interest, insurance, salaries, wages, management supplemental benefits, and union supplemental benefits. These resources cost are added to estimate the product cost. 
External Resources: External resources are acquired from external suppliers to perform activities. The external resources may vary from product to product. The costs of the external resources are added to estimate the product cost.

Internal Resources: Internal resources are produced by an enterprise activity. Each activity may produce resources after the execution. If the activity produces resource then that value of the resources should be subtracted during the estimation.

When the user types the URL for the cost management tool, it will ask for the user name and password to perform the estimation process. Once, the user is authenticated the estimation page link will direct to the estimation form sheet.

The user can select the list of activities required to produce the product and then the resource details can be entered for those selected activities. The unit cost of the resources is stored in the database; once the data is entered, the system will output the estimated cost of the product cost.

The resource costs are arrived based on the discussion and data collected from the company. The details are shown in Table 4.1.The details of equipment depreciation for each activity are shown in Table 4.2. For purposes of this report dollar values in Table 4.1 and 4.2 are not true for Celestica. These values have been assigned for example only. 


\begin{tabular}{|l|l|l|l|l|}
\hline Sl.No. & Resources & Unit & Unit cost & Reference \\
\hline 1 & Hydro & $\begin{array}{l}\text { Kilo } \\
\text { watt } \\
\text { hour }\end{array}$ & $\$ 1 / \mathrm{hr}$ & Toronto Hydro \\
\hline 2 & Heat & $\begin{array}{l}\text { Cubic } \\
\text { meter }\end{array}$ & $\$ 0.8 /$ cub.m & Enbridge, Toronto \\
\hline 3 & Water & $\begin{array}{l}\text { Cubic } \\
\text { meter }\end{array}$ & $\$ 0.75 /$ cub.m & Municipality, Toronto \\
\hline 4 & $\begin{array}{l}\text { Building } \\
\text { depreciation }\end{array}$ & $\begin{array}{l}\text { Square } \\
\text { feet }\end{array}$ & $\$ 15 / \mathrm{Sq} . \mathrm{ft}$ & Discussion \& Assumption \\
\hline 5 & $\begin{array}{l}\text { Equipment } \\
\text { depreciation }\end{array}$ & $\begin{array}{l}\text { Capital } \\
\text { dollar }\end{array}$ & $\begin{array}{l}\text { Shown in Table } \\
4.2\end{array}$ & Data collected from the company \\
\hline 6 & Property Tax & $\begin{array}{l}\text { Square } \\
\text { feet }\end{array}$ & $\$ 5 / \mathrm{sq.ft}$ & Discussion \& Assumption \\
\hline 7 & ME Salary & hour & $\$ 40 / \mathrm{hr}$ & Discussion \& Assumption \\
\hline 8 & TE Salary & hour & $\$ 42 / \mathrm{hr}$ & Discussion \& Assumption \\
\hline 9 & QE Salary & hour & $\$ 45 / \mathrm{hr}$ & Discussion \& Assumption \\
\hline 10 & $\begin{array}{l}\text { Operator } \\
\text { Wage Set up }\end{array}$ & hour & $\$ 12 / \mathrm{hr}$ & Discussion \& Assumption \\
\hline 11 & $\begin{array}{l}\text { Operator } \\
\text { Wage } \\
\text { operation }\end{array}$ & hour & $\$ 12 / \mathrm{hr}$ & Discussion \& Assumption \\
\hline 12 & $\begin{array}{l}\text { Indirect } \\
\text { benefits }\end{array}$ & hour & $\$ 1.5 / \mathrm{hr}$ & Discussion \& Assumption \\
\hline 13 & $\begin{array}{l}\text { Labour } \\
\text { benefits }\end{array}$ & hour & $\$ 0.5 / \mathrm{hr}$ & Discussion \& Assumption \\
\hline 14 & Solder paste & gram & $\$ 0.7 / \mathrm{g}$ & http://www.smtsolderpaste.com/ \\
\hline 15 & Nitrogen & $\begin{array}{l}\text { Cubic } \\
\text { feet }\end{array}$ & $\$ 3.25 / \mathrm{cft}$ & http://ceisites.com/carbon.htm \\
\hline 16 & Lubrication & Millie & $\$ 0.25 / \mathrm{ml}$ & http://www.lubesite.com/ \\
\hline
\end{tabular}

Table 4.1. Resource cost details 


\begin{tabular}{|c|c|c|c|}
\hline Sl.No. & Activity Name & Capital \$ & $\begin{array}{l}\text { Unit Cost } \\
\text { Capital/ }(5 \times \text { year } \times \text { per } \\
\text { day of operation) }\end{array}$ \\
\hline 1. & Kitting & 0 & $0 / \mathrm{hr}$ \\
\hline 2. & SMT Bottom & 2500000 & $57.08 / \mathrm{hr}$ \\
\hline 3. & SMT Top & 2500000 & $57.08 / \mathrm{hr}$ \\
\hline 4. & $\mathrm{AOI}$ & 155000 & $3.54 / \mathrm{hr}$ \\
\hline 5. & AOI Diagnostics & 155000 & $3.54 / \mathrm{hr}$ \\
\hline 6. & X-Ray & 650000 & $14.84 / \mathrm{hr}$ \\
\hline 7. & X-Ray Diagnostics & 650000 & $14.84 / \mathrm{hr}$ \\
\hline 8. & Manual & 2000 & $0.05 / \mathrm{hr}$ \\
\hline 9. & Wave Solder & 350000 & $7.99 / \mathrm{hr}$ \\
\hline 10. & Post Solder Inspection & 2000 & $0.05 / \mathrm{hr}$ \\
\hline 11. & Press fit & 42000 & $0.96 / \mathrm{hr}$ \\
\hline 12. & ICT & 600000 & $13.7 / \mathrm{hr}$ \\
\hline 13. & ICT Diagnostics & 600000 & $13.7 / \mathrm{hr}$ \\
\hline 14. & Mechanical Assembly & 2000 & $0.05 / \mathrm{hr}$ \\
\hline 15. & Manual Inspection & 2000 & $0.05 / \mathrm{hr}$ \\
\hline 16. & Track & 2000 & $0.05 / \mathrm{hr}$ \\
\hline 17. & Functional Test & 10000 & $0.23 / \mathrm{hr}$ \\
\hline 18. & FT Diagnostics & 10000 & $0.23 / \mathrm{hr}$ \\
\hline 19. & Hand Repair & 2000 & $0.05 / \mathrm{hr}$ \\
\hline 20. & Solder Fountain Repair & 15000 & $0.34 / \mathrm{hr}$ \\
\hline 21. & IC Repair & 100000 & $2.28 / \mathrm{hr}$ \\
\hline 22. & BGA Repair & 200000 & $4.57 / \mathrm{hr}$ \\
\hline 23. & Pack & 2000 & $0.05 / \mathrm{hr}$ \\
\hline
\end{tabular}

Table 4.2. Equipment depreciation

\subsection{Actual Manufacturing Cost}

Actual manufacturing cost refers to the actual cost spent to produce a product. Computing the cost of manufactured products is more complex and involves much more departmental input to arrive at the actual manufacturing cost. Different types of Cost Accounting systems are used to calculate the manufacturing costs. 
Below is the study of cost accounting system that is used to describe how the companies account the cost of the products manufactured at the company.

\subsubsection{Different types Cost Accounting Systems:}

Job Order Cost System: The job [Herrington 89] order cost system accumulates costs applicable to each specific job order or lot of similar goods manufactured on a specific order for stock or customer. When production on a job begins, the job is assigned a number, and a form called a "job cost sheet" is set up. As direct materials are used, their costs are entered on the job cost sheet. Similarly, direct labour costs incurred on a job are recorded periodically. When the job is completed, manufacturing resource costs applicable to the job are entered on the job sheet. When complete, the job cost sheet shows the total cost of the completed job. The cost per unit may then be obtained by dividing the total cost of the job by the number of units completed.

Process Cost System: The process cost system accumulates costs without attempting to allocate them during the accounting period to specific units of products being manufactured. At the end of the fiscal period, the average cost per unit is determined by dividing the total number of units produced into the total cost accumulated. Because of this technique, process costing is often referred to 
as average costing. If the process cost system is used, the products manufactured must be similar in nature so that an average cost will be meaningful.

Dual Systems: Some manufactures use both the job order cost and process cost system. A dual system is often used when a company makes standard parts of subassemblies continuously and then incorporates them into finished goods that are built to customer specifications. The cost of the parts is accumulated and determined under a process cost system, and the cost of each customer's order for finished products is computed under a job order cost system.

In this research, the activities resources are classified into four major categories and the method of cost accounting is the same as job order costing.

Since the costing tool is available on the Internet, any authorised persons from the company can access the costing tool to make entries. The organization should establish clear systems to record the cost flows.

Each activity is subject to consume the following resources; the possible ways to record the resources are described below:

Non-Period Resources: Non-period cost external resources such as hydro, heat and water can be measured by installing a separate meter to note the units consumed to produce the products. 
Period Cost Resources: Period cost resources that are time dependent (e.g. building depreciation, equipment depreciation, property taxes, borrowed capital interest, insurance, salaries, wages, management supplemental benefits, and union supplemental benefits) should be based on the actual hours spent on the products.

External Resources: External resources are acquired from external suppliers to perform activities. External resources can be tracked by computing actual quantity taken from the stores to build the products.

Internal Resources: The internal resource is produced by an enterprise activity. The value of the internal resources is calculated based on the quantity produced by each activity.

The company should form the cost committee and the responsibility should be given to employees at all level. The Fig.4.3 illustrates, the proposed organization chart to record cost flow of the activities. 


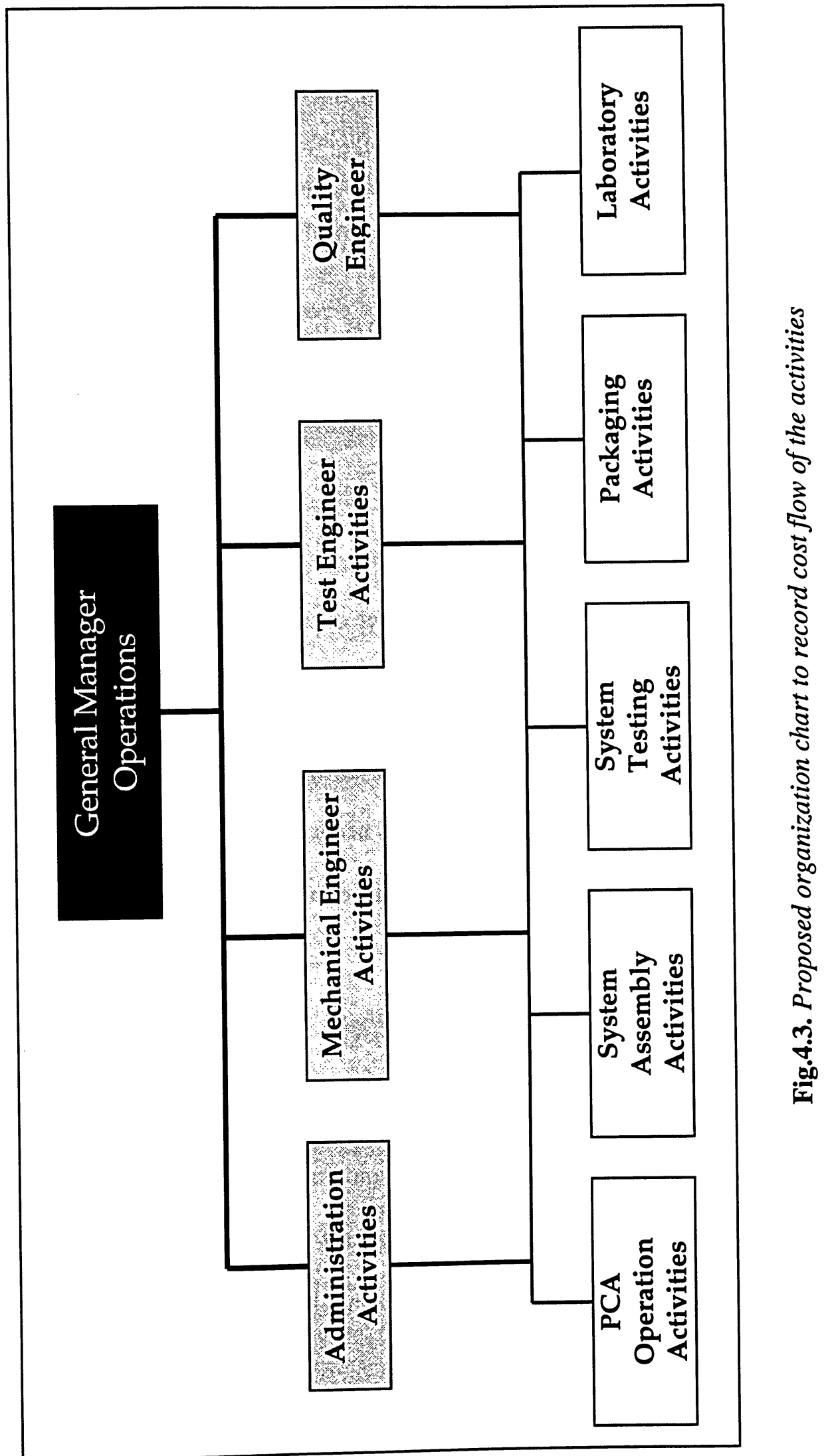




\subsection{Tracking}

The most important concept in developing the cost management tool is to trace cost behaviour and cost variance. The number of activities needed to build the product and the activities resources are to be tracked to find the variation in cost. Also, the resource consumption pattern should be traced for controlling costs.

The tracking module in the cost management tool is built to track the following information:

- The estimated cost of order X

- The actual cost of order $\mathrm{X}$

- The cost variation of product $\mathrm{X}$

- The total number of order produced for the customer X

- The cost resources spent for product $\mathrm{X}$ and so on...

The estimated resource values and the actual resource spent values are stored in the database; therefore, further data can then be retrieved as needed.

More on tracking is explained with data in results and discussion chapter.

\subsection{Scope and Capability of the Prototype}

The prototype is developed to demonstrate the concept and no security features are added to it. The input field should be filled with data otherwise it will treat the data value as null. Forms are not validated and the incomplete form cannot be saved. 
- Any number of users can use the system and new usernames can be created using the database.

- All enterprise activities can be added directly to the database.

- Any number of products can be estimated and the database is able to store the data.

- Additional resources can be added to the database.

- Limited queries are linked through the prototype and any queries related to the product, customer, activities and resources could be written to get the output. 


\section{CHAPTER 5}

\section{RESULTS AND DISCUSSION}

The prototype was developed using the Temporal Activity-Based Costing principle. After conducting five estimations of hypothetical products, actual manufacturing entries and tracking, it has been observed that the proposed web-based cost system will enable the management to have effective control over the activities of resource costs.

The accuracy of product cost depends on recording the actual manufacturing resource costs. Assumptions are made to enter the actual manufacturing resources.

The performance of the cost system analysed for five fictitious products and the cost of production and the usage of resources are shown below. The sample resource data entered into the web-basd cost management tool are shown in Table.5.1. 

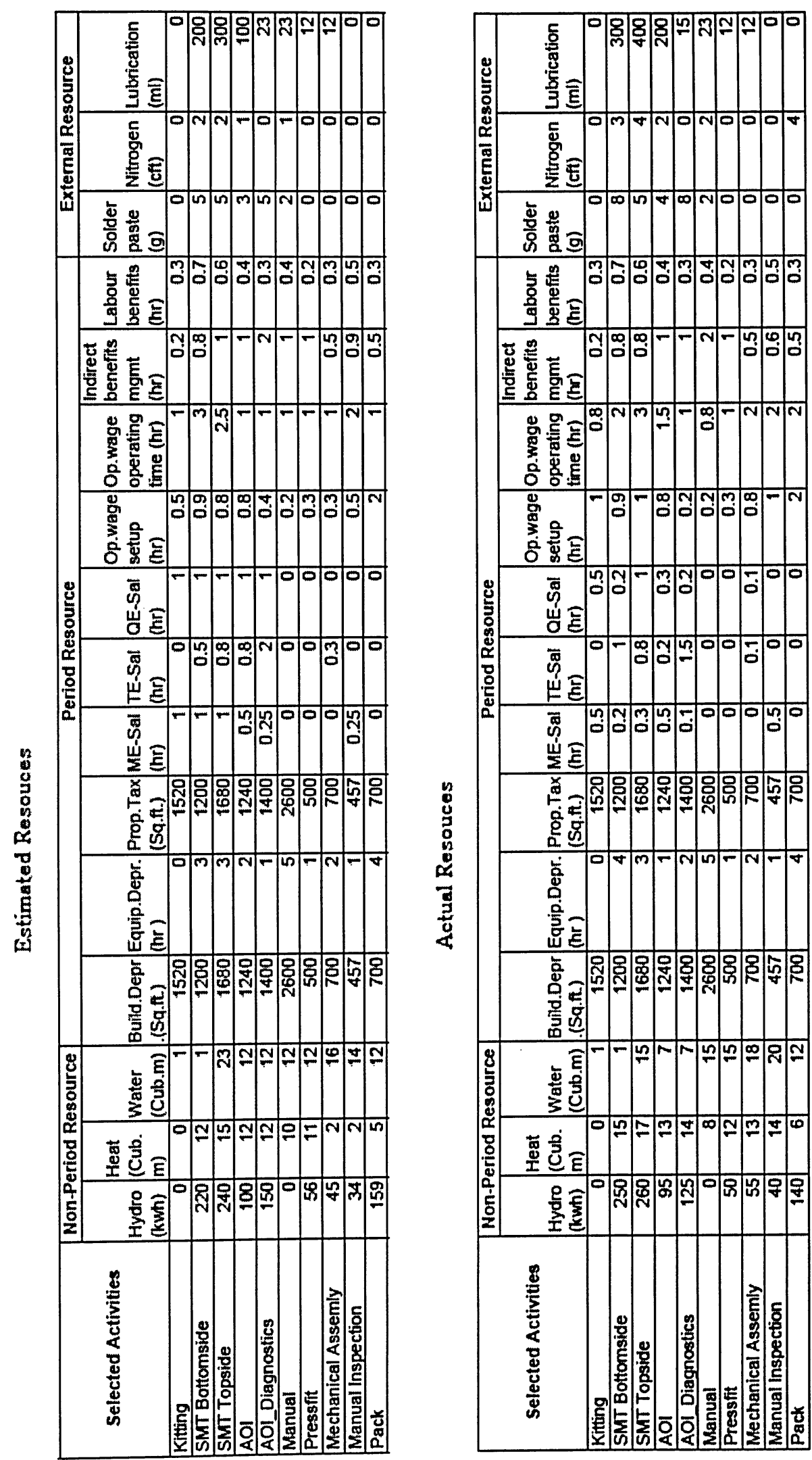

宫参.
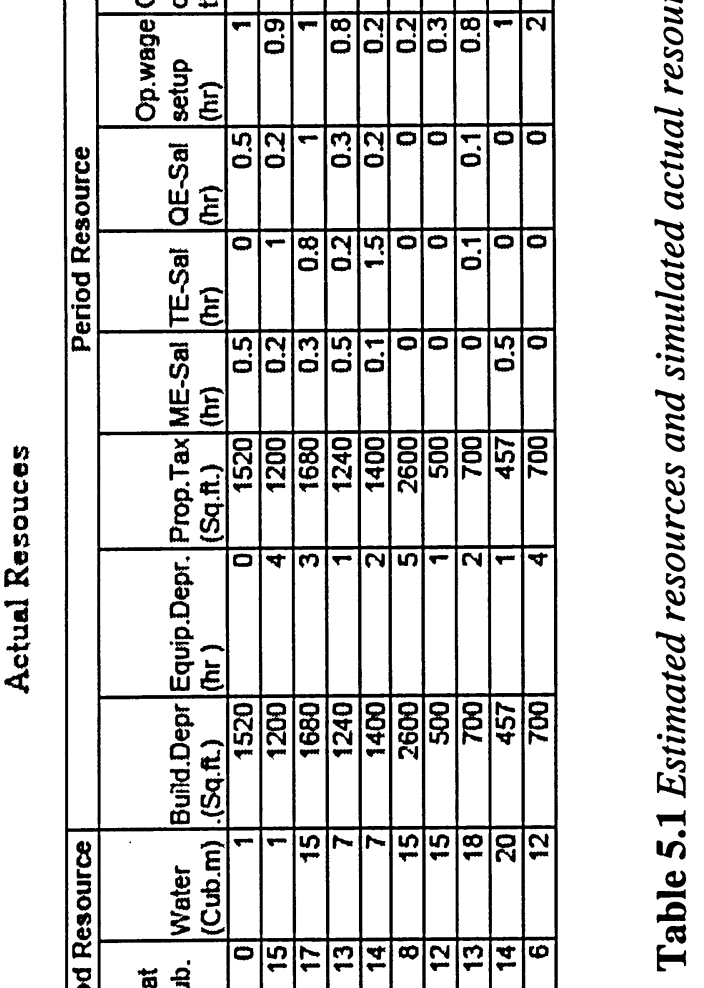

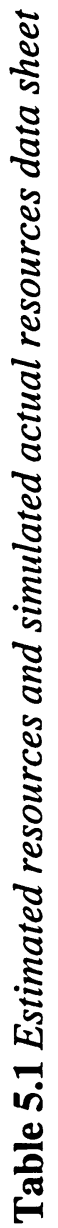

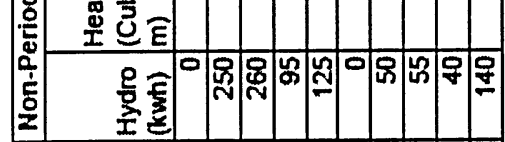


Table 5.2 shows the customer details, the product cost estimated and the actual cost obtained from the cost management tool for five products.

\begin{tabular}{|l|c|c|}
\hline & \multicolumn{2}{|c|}{ Products } \\
\hline & Estimated Cost \$ & $\begin{array}{c}\text { Simulated } \\
\text { Actual Cost \$ }\end{array}$ \\
\hline Customer 1 & 24212 & 28205 \\
\hline Customer 2 & 38012 & 33510 \\
\hline Customer 3 & 33500 & 38500 \\
\hline Customer 4 & 44000 & 38631 \\
\hline Customer 5 & 33568 & 36532 \\
\hline
\end{tabular}

Table 5.2. Customer order estimated cost and actual cost

Fig. 5.1 illustrates the difference of the costs estimated and the actual costs spent to manufacture the product. If a company implements this system, then the management will be able to track the product's costs after completion of each order. 


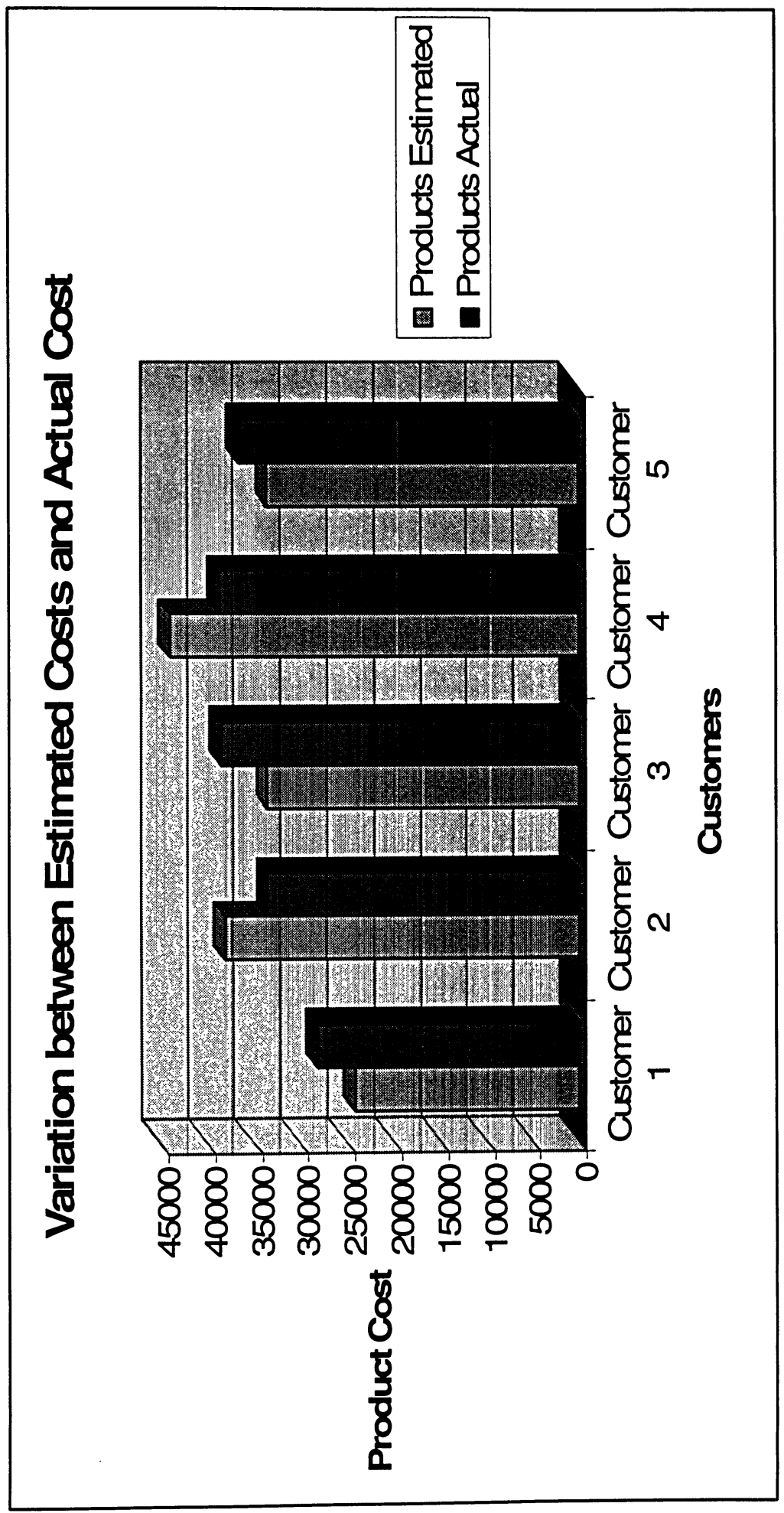

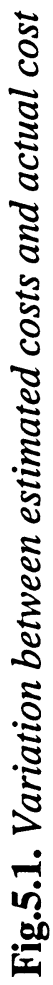


Table 5.3 shows the hydro resource data. This kind of comparison will enable the plant managers to control over the resources.

\begin{tabular}{|l|c|c|}
\hline & \multicolumn{2}{|c|}{ Hydro (kwh) } \\
\hline & Estimated & $\begin{array}{c}\text { Simulated } \\
\text { Actual }\end{array}$ \\
\hline SMT Bottom side & 35 & 50 \\
\hline X-Ray & 12 & 20 \\
\hline Manual & 5 & 10 \\
\hline Wave Solder & 6 & 5 \\
\hline Solder Fountain & 8 & 70 \\
\hline Pack & 60 & 0 \\
\hline Kitting & 0 & 8 \\
\hline
\end{tabular}

Table 5.3. Hydro variation data

Fig.5.2 shows the hydro cost variation. If management train the shop floor employees, with the help of this kind of resource variation pictures, then they could also be involved in this cost saving process. 


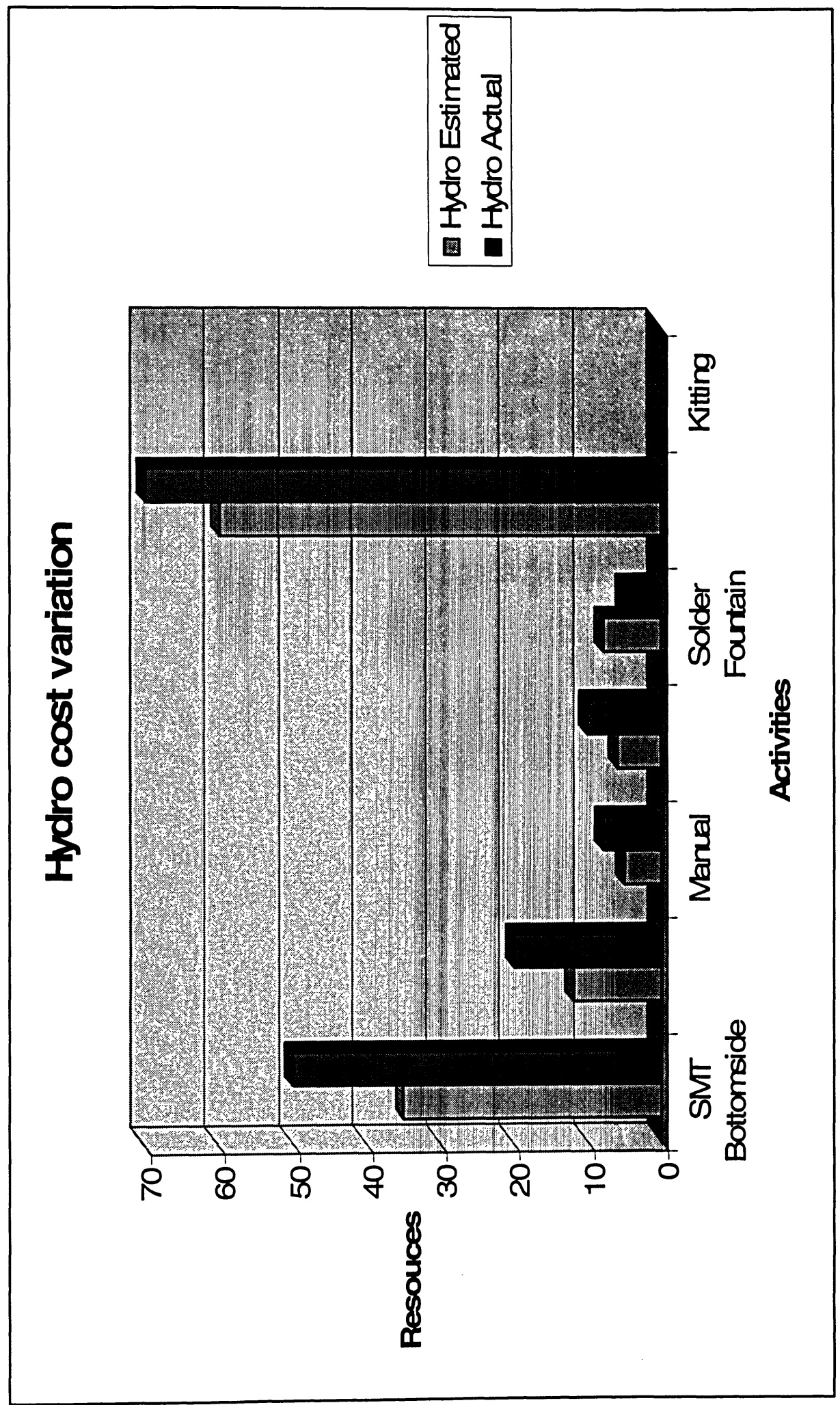

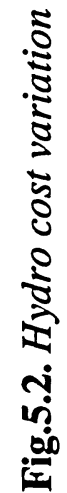


External resource variation is shown in Table 5.4.

\begin{tabular}{|l|c|c|}
\hline & \multicolumn{2}{|c|}{ External Resource Units (cft) } \\
\hline & Estimated & $\begin{array}{c}\text { Simulated } \\
\text { Actual }\end{array}$ \\
\hline SMT Bottom side & 35 & 50 \\
\hline X-Ray & 12 & 20 \\
\hline Manual & 5 & 8 \\
\hline Wave Solder & 6 & 10 \\
\hline Solder Fountain & 8 & 5 \\
\hline Pack & 60 & 70 \\
\hline Kitting & 0 & 0 \\
\hline
\end{tabular}

Table 5.4 External resource variation data

As seen in Fig.5.3 this system could help management to track the external resource consumption to product per volume. This kind of consumption will enable the organisation to have proper inventory control. Likewise, all resource variation can be obtained from the developed cost management tool. 


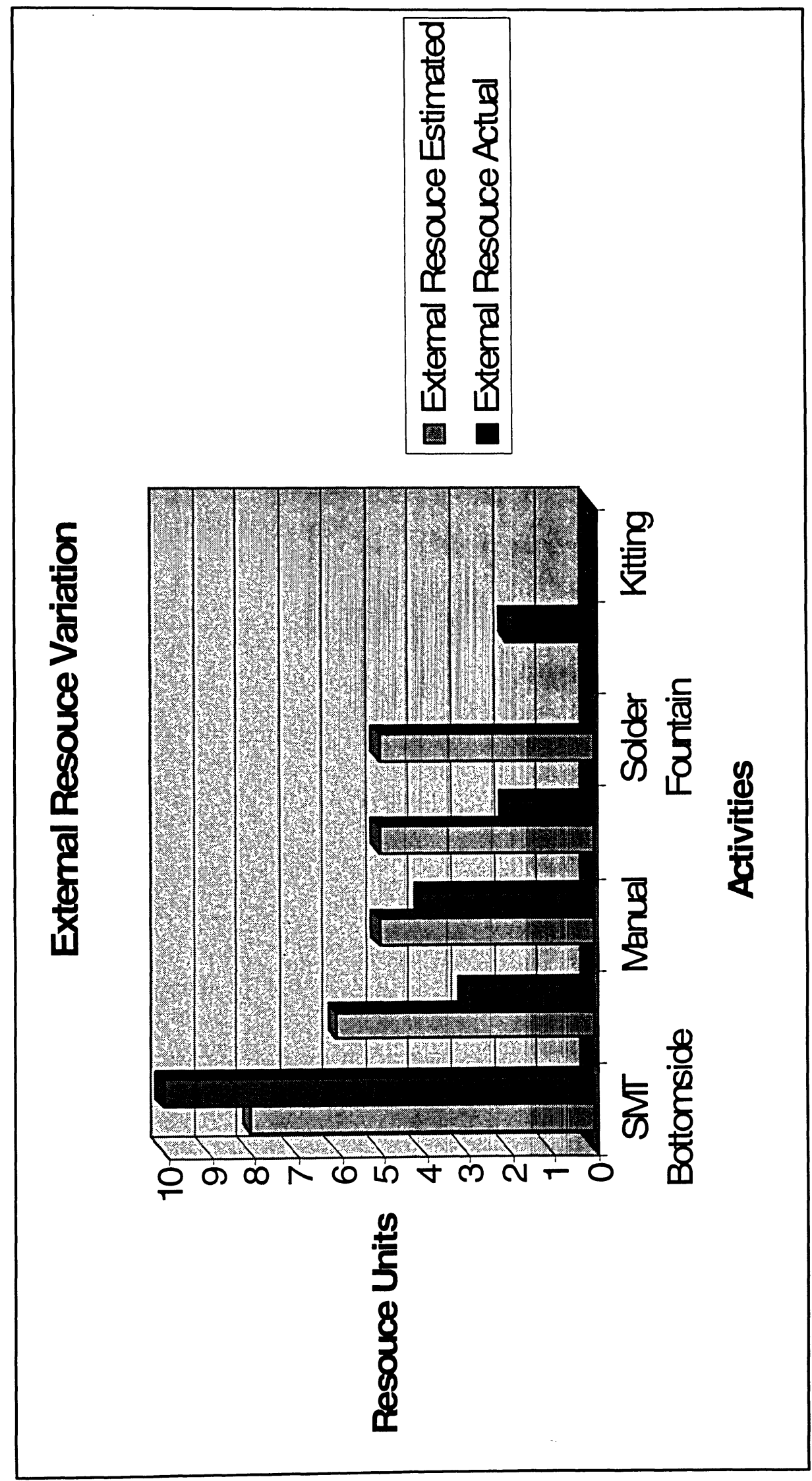

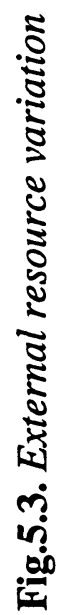
in 


\section{CHAPTER 6}

\section{CONCLUSIONS AND FUTURE WORK}

\subsection{Conclusions}

In this research, web-based cost management tool prototype has been developed for estimation, actual manufacturing and tracking of product cost. Also, an enterprise's activities and resources are generalised. The present costing system has no direct provision to track the product cost. Hence, the developed prototype will enable the management to have control over the product costs.

The research was conducted in the electronics industry through the manufacturing process activities. The proposed cost model implemented the Temporal-ABC ${ }^{\circledR}$ cost estimation process. Also, the way to capture actual product cost is proposed. The proposed tracking is intended to provide all order related cost information as needed.

The cost management system by itself will not produce profitability to the organization; however, it will facilitate managers to take corrective and better decision at the right time.

The summary of the work and future extension of the work is presented in this chapter. 


\subsection{Future Work}

This research has the potential to encourage further research in the field. In the following, proposed some ideas that could lead to future research recommendations:

- The application development should be extended to include commit, disenabled and re-enabled state of the resources.

- The scope of the research is limited to the manufacturing sector. However, the research may be applied to the non-manufacturing sector such as banking and other service industries.

- Assumptions are made to capture actual manufacturing cost. Further research can be conducted to discover a better way to capture actual times and resources used.

- More research needs to be undertaken towards the security of acquisition and transmission of cost data. 


\section{REFERENCES}

1. [Atkinson 87]

Atkinson, Anthony A., "Cost estimation in management accounting-six case studies", The society of management accountants of Canada, 1987.

2. [Awasthi 94]

Awasthi, Vidya N., "Activity-Based Costing: A model for implementing change", IEEE, 1994.

3. [Bergsten 01]

Bergsten, Hans., "Java Server Pages", O'Reilly publications, 2001.

4. [Cooper \& Kaplan 92]

Cooper, Robin and Kaplan, Robert S., "Activity-Based Systems: Measuring the Costs of Resource Usage", Accounting Horizons, September 1992.

5. [Eden \& Maingot 02]

Eden, Ron and Maingot, Michael "Activity based costing in the high technology industry in Canada", European accounting association, April, 2002.

6. [Gunasekaran \& Sarhadi 98]

Gunasekaran, A and Sarhadi M., "Implementation of Activity-based costing in manufacturing", Elsevier 1998.

\section{7. [Herrington 89]}

Herrington, Brock Palmer., "Cost accounting principles and applications”, Gregg Division McGraw-Hill book company, 1989. 


\section{8. [Hicks 92]}

Hicks, Douglas T., “Activity based costing for small and mid-sized business", Wiley professional paperback series, 1992.

\section{9. [Hicks 99]}

Douglas T. Hicks, "Activity based costing making it work for small and mid-sized companies", Wiley professional paperback series, 1999.

10. [Malmi 97]

Malmi, Teemu., "Towards explaining activity-based costing failure: accounting and control in a decentralized organization", Management Accounting, 199.

\section{1. [Partovi 91]}

Partovi, Fariborz Y., "An analytic hierarchy approach to activity-based costing”, Elsevier Science Publishers, 1991.

12. [Staubus 71]

Staubus, George J., "Activity costing and input-output accounting", Richard D. Irwin, Inc, 1971.

\section{3. [Tham \& Fox 04]}

Tham, K. Donald K. and Fox, Mark S., "Determining requirements and specifications of enterprise information systems for profitability", ICEIS 2004.

\section{4. [Tham 99]}

Tham, Kokchu Donald "Representing and reasoning about costs using enterprise models and ABC", Thesis for Doctor of Philosophy, University of Toronto, 1999. 
15. [Tornberg et al. 02]

Tornberg, Katja and Jamsen, Miikka and Paranko, Jari., "Activity-based costing and process modeling for cost-conscious product design: A case study in a manufacturing company", Elsevier Science, 2002.

16. [Tzvi \& Elnathan 99]

Raz, Tzvi and Elnathan, Dan., “Activity based costing for projects”, International journal of project management, Vol.17, pp 61-67, 1999.

17. [Waeytens \& Bruggeman 94]

Waeytens, Dominique and Bruggeman, Werner., "Barriers to successful implementation of ABC for continuous improvement: A case study", Elsevier Science, 1994. 


\section{Appendix A: Prototype web-pages printouts}

Celestica Cost Management System

Page 1 of 1

Home $\quad \mid$ Feedback $\mid$ Contents $\mid$ Search $\mid$

\section{Celestica Cost Management System}

\section{Estimation Actual Cost Tracking}

\section{Our Mission}

Saving cost through effective control...

\section{Company Profile}

Celestica is a world leader in the delivery of innovative electronics manufacturing services (EMS). Celestica operates a highly sophisticated global manufacturing network with operations in Asia, Europe and the Americas, providing a broad range of integrated services to leading original equipment manufacturers (OEMs) across a variety of industries.

\section{Contact Information}

\section{Telephone}

FAX

Postal address

1150 Eglinton Avenue East, Toronto, Ontario $\mathrm{M} 3 \mathrm{C}$ 1H7, Canada

Electronic mail

General Information:

Sales:

Customer Support:

Webmaster: 
Celestica Cost Management Tool for Manufacturing Process

User Authorization Page

\author{
Enter User Name murugs \\ Enter Password
}

Login Reset 
Page 1 of 1

\section{Celestica Cost Management Tool for Manufacturing Process}

Please select required function

Cost estimation

Actual manufacturing cost

Tracking process 


\section{Celestica Cost Management Tool for Manufacturing Process Cost Estimation Process}

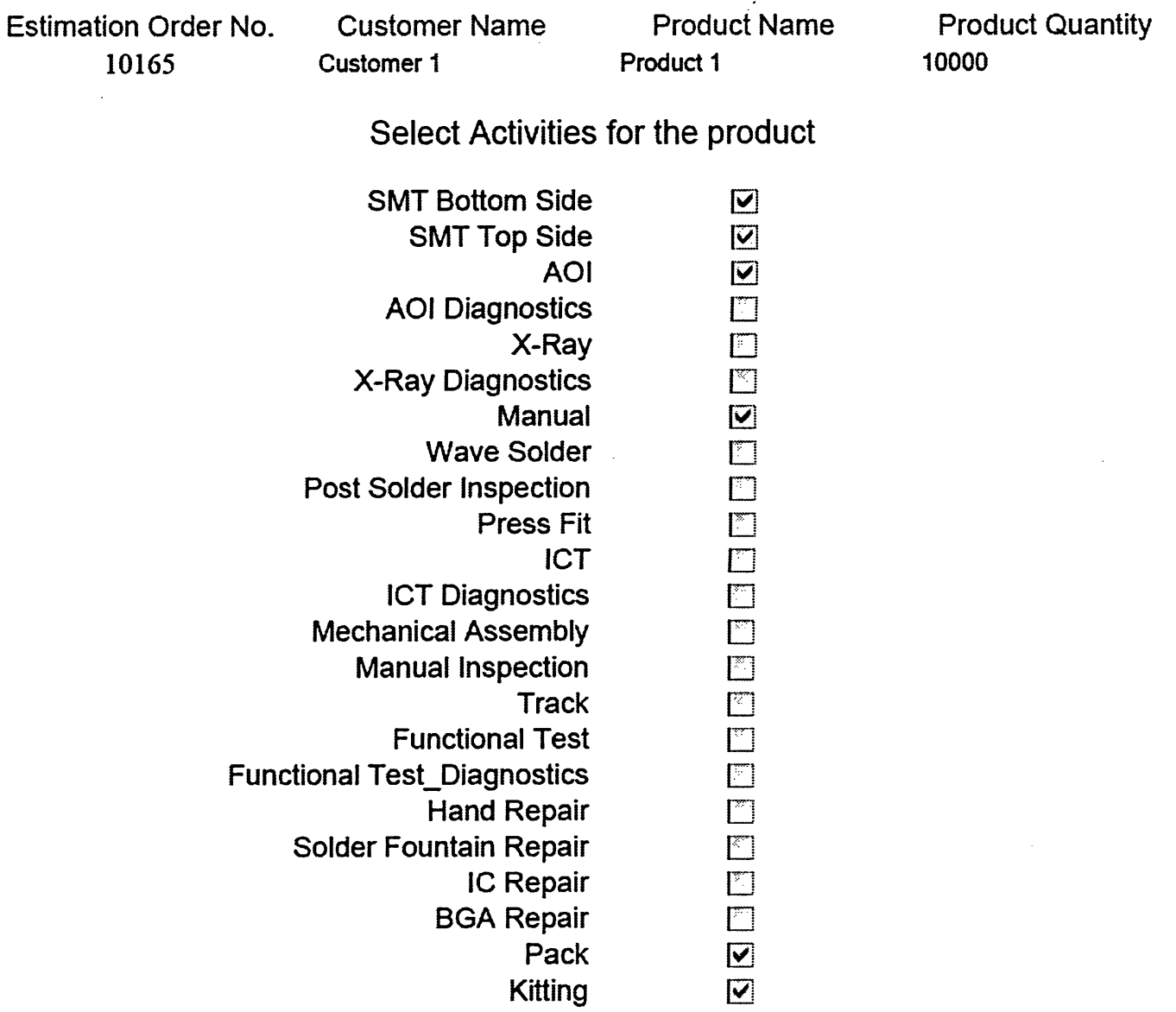




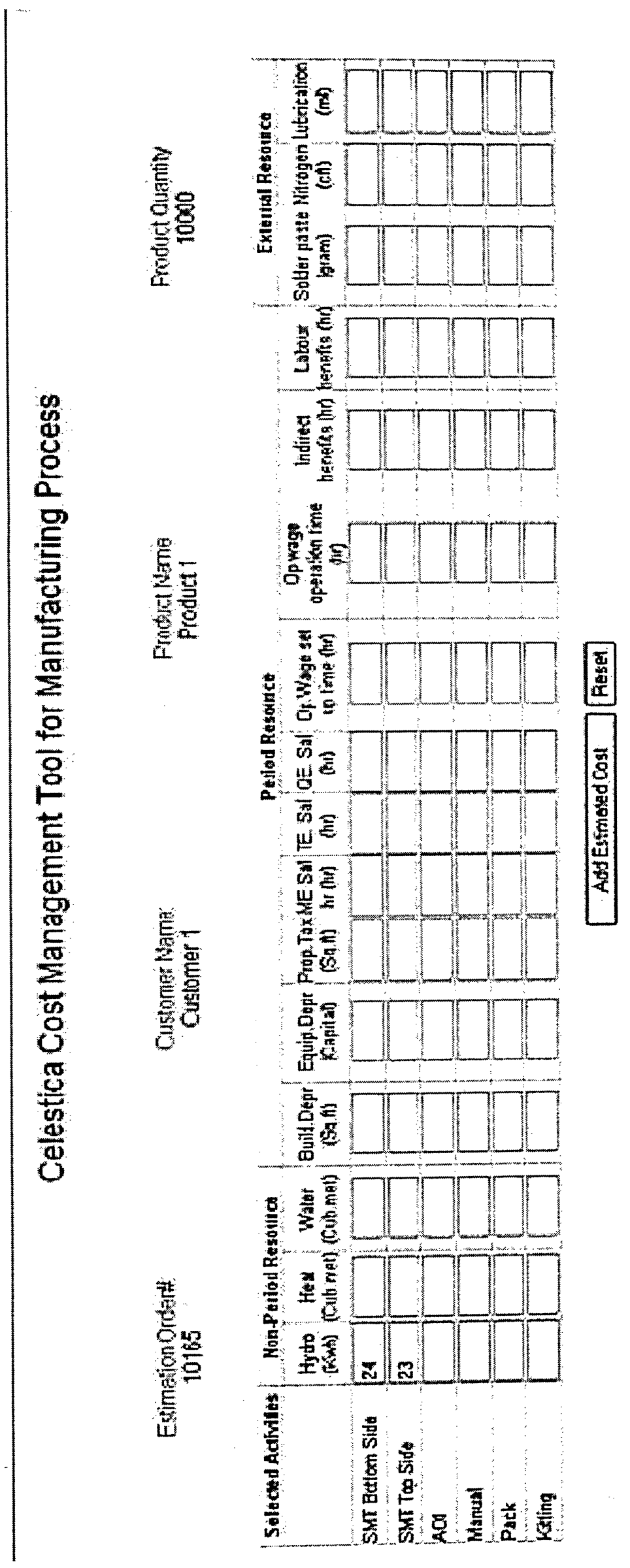

$\sqrt{6}$ 


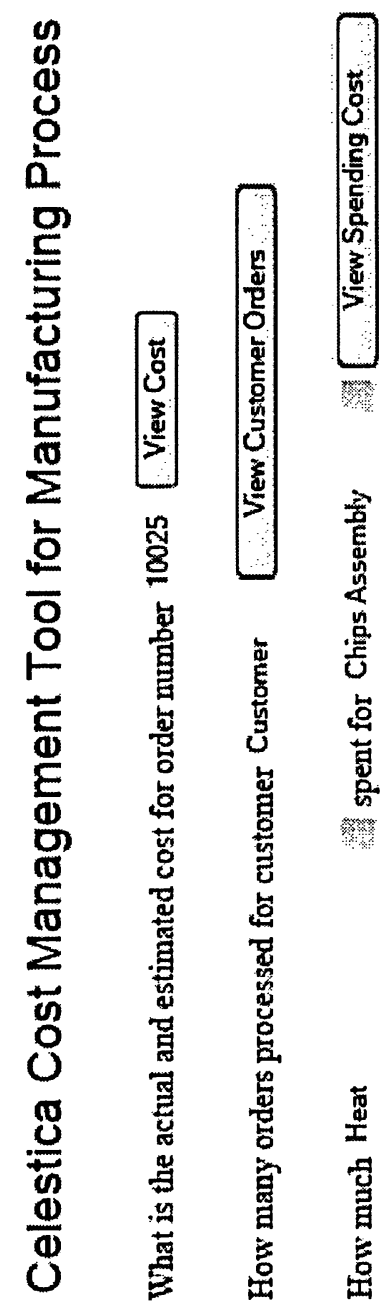

(3) Et-Lio- 60 